\title{
A quantitative approach to the 2014 Mt. Ontake volcanic eruption news coverage: understanding the information gap and the public response to the anniversary coverage
}

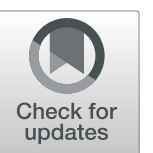

\author{
Ko Yamada (1)
}

\begin{abstract}
This paper studies the news coverage of the 2014 Mt. Ontake eruption disaster from 2015 to 2019, and the public response to the fifth anniversary coverage. Information on the issues regarding the risk of low-frequency disaster events such as volcanic eruption is brought into the public largely through the media. Unless there is a volcano nearby, there are few opportunities to discuss volcanic disaster prevention, and enhance volcanic risk perception. Therefore, the media agendas on volcanic risk are an indicator of what people know about volcanic disaster preparedness. This study quantitatively analyzed the 2014 Mt. Ontake eruption reports of national, regional, and local newspapers to reveal their topic distributions. In addition, the anniversary gained intense public attention due to the large amount of media coverage. It was a significant opportunity for society to discuss volcanic risk. By observing people's online responses to the anniversary coverage, a trend could be identified. We found a significant difference in media attention among the three newspaper types. The local newspaper covered four topics relating to volcanic risk in a well-balanced way, but the national and regional newspapers paid greater attention to one or two topics. Many online comments presented the view that a mountaineering should be done at individuals' own risk, and volcano shelters would be ineffective for averting volcanic disasters. The anniversary coverage unintentionally contributes to stigmatizing or scapegoating a certain group, rather than promoting risk communication in the public sphere on the Web. With the onset of the information and communication information technology era, an online dialogue regarding disaster awareness and prevention is important. A volcano disaster risk communication strategy on the Web should be developed.
\end{abstract}

Keywords: Volcanic disaster, Content analysis, Text mining, Risk communication, Collective memory

\section{Introduction \\ Background}

On September 27, 2014, Mt. Ontake erupted on the border between Japan's Nagano and Gifu prefectures. This steam-driven, phreatic explosion led to the worst volcanic disaster in post-war Japan, with 63 fatalities (five individuals are still missing) and 69 injured (The volcanic

Correspondence: yamada-k@yasuda-u.ac.jp

Department of Current Business, Yasuda Women's University, Yasuhigashi, Asaminami-ku, 731-0153 Hiroshima, Japan emergency mitigation plan committee for Sabo of the Ontake volcano 2018). The 2014 eruption of Mt. Ontake occurred when the volcanic alert level of the Japan Meteorological Agency (JMA) was at its lowest. The eruption received extensive media attention, raising public awareness of volcanic risk, and led to the reform of legal frameworks for volcanic disaster risk reduction and management. This calamity is considered a milestone in volcanic risk management in Japan. Table 1 and Fig. 1 portray the timeline of volcanic warnings about Mt. Ontake and a map around Mt. Ontake, respectively.

(c) The Author(s). 2022 Open Access This article is licensed under a Creative Commons Attribution 4.0 International License, which permits use, sharing, adaptation, distribution and reproduction in any medium or format, as long as you give appropriate credit to the original author(s) and the source, provide a link to the Creative Commons licence, and indicate if changes were made. The images or other third party material in this article are included in the article's Creative Commons licence, unless indicated otherwise in a credit line to the material. If material is not included in the article's Creative Commons licence and your intended use is not permitted by statutory regulation or exceeds the permitted use, you will need to obtain permission directly from the copyright holder. To view a copy of this licence, visit http://creativecommons.org/licenses/by/4.0/. The Creative Commons Public Domain Dedication waiver (http://creativecommons.org/publicdomain/zero/1.0/) applies to the data made available in this article, unless otherwise stated in a credit line to the data. 
Table 1 Timeline of events associated with the 2014 volcanic eruption of Mt. Ontake

\begin{tabular}{|c|c|}
\hline Date & Event \\
\hline 1979 & A phreatic explosion at Mt. Ontake volcano (VEI 2) \\
\hline 2007 & A phreatic explosion at Mt. Ontake volcano \\
\hline Sep 10-16, 2014 & $\begin{array}{l}\text { An increase in volcanic earthquakes was } \\
\text { observed (the volcanic alert level 1). }\end{array}$ \\
\hline Sep 27, 2014 & $\begin{array}{l}\text { A phreatic eruption occurred at Mt. Ontake, and } \\
\text { the JMA raised the volcanic alert level for } \\
\text { Mt. Ontake from } 1 \text { to } 3 \text {. }\end{array}$ \\
\hline Oct 16, 2014 & Relief efforts were completed. \\
\hline Jan 19, 2015 & $\begin{array}{l}\text { The JMA set the access-limited area to within } 3 \\
\mathrm{~km} \text {. }\end{array}$ \\
\hline Jun 26, 2015 & The alert level for Mt. Ontake was lowered to 2. \\
\hline Jul 1, 2015 & $\begin{array}{l}\text { The Act on Special Measures Concerning Active } \\
\text { Volcanoes was amended. }\end{array}$ \\
\hline Jul 29, 2015 & The search resumed for those listed as missing. \\
\hline Jul 31, 2015 & $\begin{array}{l}\text { One body was recovered from a search, resulting } \\
\text { in } 58 \text { deaths and five missing persons. }\end{array}$ \\
\hline Aug 6, 2015 & $\begin{array}{l}\text { The search effort for missing persons was called } \\
\text { off. }\end{array}$ \\
\hline Dec 10, 2015 & $\begin{array}{l}\text { The revised Act on Special Measures Concerning } \\
\text { Active Volcanoes was brought into force. }\end{array}$ \\
\hline
\end{tabular}

Jun $282016 \quad$ Some restrictions on mountain trails were lifted.

Sep 24, $2016 \quad$ The mountain trail up to the ninth station was allowed on the side of the village of Otaki.
$\operatorname{Jan} 25,2017$

Aug 21, 2017

Jan 23, 2018

Sep 21, 2018

Sep 26, 2018

Jul 1, 2019

A group of bereaved families filed a lawsuit against the local government and the JMA, claiming that they failed to raise the alert level when there was an increase in volcanic earthquakes at the beginning of September, 2014.

The alert level for Mt. Ontake was lowered to 1.

Phreatic explosion at Mt. Kusatsu-Shirane volcano, resulting in one fatality.

A group of bereaved families searched for missing individuals.

The town of Kiso lifted restrictions for going to the summit of Mt. Ontake (until Oct. 8th). Some grieving families climbed to the summit.

The town of Kiso lifted restrictions for going to the summit of Mt. Ontake (until Oct. 16th).

Source: Information taken from articles of the Shinano-Mainichi Shimbun, whose titles are "Events related to the volcanic eruption of Mt. Ontake" (September 26, 2019), and "The volcanic eruption of Mt. Ontake: Five years of recovery" (September 26,2019 ) and the JMA (Japan Meteorological Agency 2020). According to the JMA, each volcanic alert level for Mt. Ontake is explained as follows: Level 1: Normal level but keep the active volcano in mind, Level 2: Eruptions that affect an area around a crater could occur, Level 3: Eruptions that cause heavy damage to the vicinity of residential areas could occur

According to the Act on Special Measures Concerning Active Volcanoes, amended after the eruption of Mt. Ontake, hikers and tourists themselves need to take steps to mitigate damage because only tangible factors like shelters are insufficient to save people's lives from volcanic disasters, although disaster risk reduction is primarily a government's task. The Sendai Framework for Disaster Risk Reduction 2015-2030 (United Nations 2015) calls for a preventive approach by various relevant stakeholders in disaster risk reduction and management. Normally, people are not keen to conduct preliminary mitigation and preparedness measures because there is a lack of information about how to cope with natural disaster risks at an individual level. For those who complete formal education, mass media, especially TV and newspapers, are important avenues for acquiring scientific knowledge (National Institute for Environmental Studies 2015; Ministry of Education 2015). While newspaper circulation has steadily declined over the years, newspapers are still among the most credible sources of information (Nakai 2018). It is noted that each generation acquires news through various media channels at a different rate (Institute for Information and Communications Policy 2019). However, media have a tendency to cover similar subjects (Hagiwara 2000), because journalists share similar ideas in terms of news values, which determine the stories to be selected (Wendelin et al. 2017). By examining newspaper content, we can therefore understand which topics regarding volcanic risks are mainly transmitted to society.

\section{Anniversary coverage}

Media coverage on disaster and risk issues plays a leading role in increasing awareness of risk before future hazards strike. It also helps people to interpret the meaning of past natural catastrophes and conditioning how they respond to and what are politically prioritized (Pantti et al. 2012). Anniversary journalism focuses on the anniversaries of certain historical events, creating a community's shared understanding of its past, and handing down lessons learned to future generations. Therefore, anniversary journalism substantially affects the "collective memories" (van Dijck 2007; Edy 2019) of preceding events. Sociological scholars have suggested that "collective memories are shared representations of a group's past based on a common identity" (Halbwachs 1992; Licata and Mercy 2015). In reconstructing a previous incident, collective memory is crafted through an interaction between public and private forms of memory, and greatly influenced by the media. In sociological frameworks, memory is treated as a social product and a category of cultural knowledge (Schwartz 1990; Edgerton 2000), as recollections are ingenerated from social experiences linked to social systems and identity. In Japan, September 1, the day of the 1923 Great Kanto Earthquake, has been designated as Disaster Preparedness Day (Bosai no Hi in Japanese) to raise disaster awareness since 1960. Mizude (2016) noted that the newspapers utilized memories of the Great Kanto Earthquake to give the meaning of a day, on which the importance of disaster preparedness is realized 


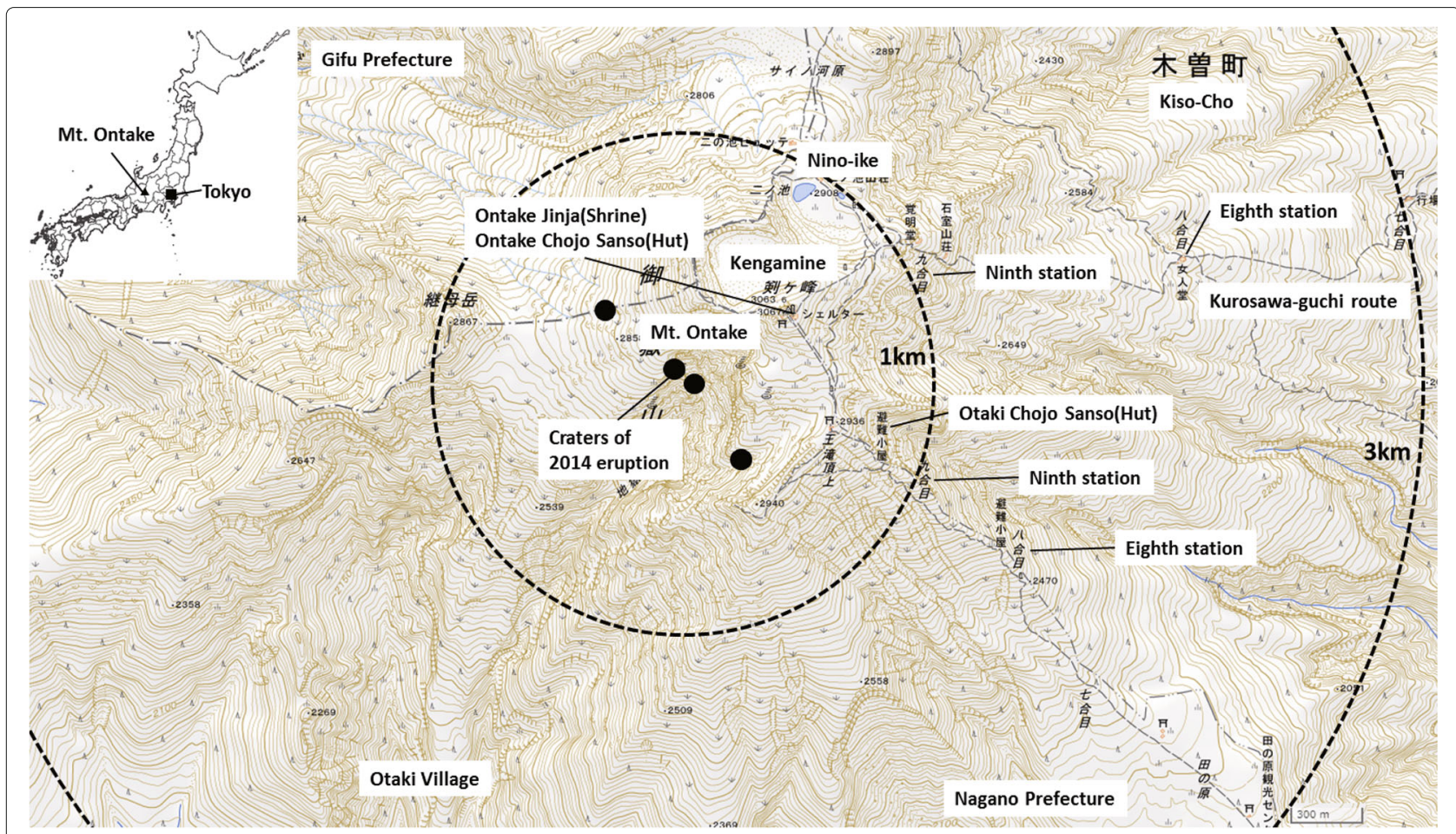

Fig. 1 Map around the summit of Mt. Ontake, based on the digital topographic data published by the Geospatial Information Authority of Japan. The filled circles indicate the craters of the 2014 eruption. The inner and outer dotted lines denote the range of $1 \mathrm{~km}$ and $3 \mathrm{~km}$ from the crater area, respectively. The casualties were discovered within the $1 \mathrm{~km}$ region (Tsunematsu et al. 2016)

again, to the Disaster Preparedness Day, and the fading memory of the Great Kanto Earthquake was refreshed at the national level by the establishment of an official day in 1960 (Mizude 2016). According to Edgerton (2000), news media have the power to reinterpret previous occasions, especially in the digital age. Group memories are constructed via diverse media channels such as newspapers, $\mathrm{TV}$, and online news.

Anniversary coverage reflects current social perspectives. Examining news coverage of the Tiananmen Square crackdown, and the fall of the Berlin Wall from 1990 to 2011 in the New York Times and the Washington Post, $\mathrm{Li}$ and Lee (2013) found that these two elite newspapers harbored a rigid anti-Communist attitude in the era of the post-Cold War. Hence, their anniversary journalism adopted a non-objective stance on the issues involved. In light of the media agenda-setting theory, which posits that audiences receiving a message will consider the topics to be important when mass media stress some topics over others (McCombs and Shaw 1972; Takeshita 2008), Kligler-Vilenchik et al. (2014) compared the "media memory agenda" and the "public memory agenda" to determine the media's influence in shaping collective perceptions of the past on the 60th anniversary of Israel's establishment. They found that heavy exposure to televised media memory enabled people to consider Israel's 60th anniversary as the most important event in the nation's history.

As for memories of catastrophic incidents, Su (2012) investigated reporting on the 10th anniversary of the 921 Taiwan Earthquake (1999) through narrative analysis, to understand how news media represented the collective memory of this calamity. The results showed that journalists used memories to produce a discourse assessing the government's risk management of analogical catastrophic events and that shared memories converged into conventional stories of individual survival experiences and practical lessons learned. Robinson's study (2009) (Robinson 2009) on the anniversary coverage of Hurricane Katrina delineated the unique agenda-setting role of national and local newspapers. The national media set the political agenda to clean up and rebuild New Orleans, and conveyed lessons learned from the subsequent chaos to the American people. Local media reconnected neighborhood communities by creating stories that evoked feelings of residential satisfaction and a common identity. The press can contribute considerably to strengthening and/or restoring social cohesion by unifying individuals' experiences into mutual memories, and reaffirming existing social norms (Robinson 2009; Kitch and Hume 2007). Trümper and Broer (2019) indicated that journalists take 
advantage of eyewitness accounts to make claims about the present and the future. Shared memory enables journalists to highlight latent problems in the public sphere, prompt preventive or protective actions, and encourage debate on how social problems should be politically addressed.

\section{Risk perception and the media}

Risk perception depends on historical and cultural contexts. Paton et al. (2010) identified similarities between Japan and New Zealand regarding how intentions to take earthquake preparedness actions were controlled by variables such as outcome expectancies, community participation, collective efficacy, and trust. Another group of scholars demonstrated that a "sense of collectivity"a feeling of participation in one's community-is an important factor in forecasting preparedness behavior (Unagami et al. 2012). For example, the stronger one's emotional attachment to one's home, the more likely one is to take protective measures (Evans et al. 2004; Tierney et al. 2001; Kim and Kang 2010). In addition, people who acquire knowledge of natural disasters exhibit intense preparedness-related conduct (Perry and Lindell 1990; Showalter 1993). In general, someone with higher self-efficacy (Bandura 1977) is more likely to take action to prepare for disasters (Paton 2003). Cognitive expectancy theory implies that expectations of personal efficacy depend upon four sources of information: "performance attainment, vicarious experiences, verbal persuasion, [and] physiological and emotional arousal" (Bandura 1977).

Regarding catastrophic wildfires in Colorado, Kroepsch et al. (2018) suggested that while local media conveyed messages about learning and adaptation in early anniversary commemorations of such events, the discourse on these two themes faded in later anniversaries. Generally speaking, local media help to create a sense of collectivity, and of being part of one team (Pollock 2014). The selective memory of preceding events helps journalists guide public attention toward contemporary uncertainties as well as potential future threats, thereby allowing people to cope with these matters (Adam 2004; Nowotny 2008). Public opinion polls on disaster prevention (Cabinet Office 2017) report that the most useful sources of information on natural catastrophes include disaster reporting, hazard maps, TV programs, and past memories. Thus, media are involved in vicarious experiences and verbal persuasion by providing information on memories of previous natural risks.

\section{Objectives}

Describing the relationship between the four actors residents, the government, mass media, and experts - as the tetrahedron of disaster mitigation, previous studies emphasized that the cooperative relationship between the government, mass media, and experts is significant for retaining the tetrahedron (Okada and Ui 1997; Okada 2015). Our research primarily aimed to discover the kind of information newspaper media provided to Japanese society in terms of the 2014 eruption of Mt. Ontake because the media has the power to shape collective memory, leading to shared perception of volcanic risks. Understanding what information is valued and what is overlooked in the media sphere will help remove the gap between experts and journalists when experts endeavor to collaborate with them.

A disaster management cycle is divided into four phases: mitigation, preparedness, response, and recovery (Federal Emergency Management Agency 2006). It is assumed that media are crucial management tools because of their ability to widely and promptly transmit information about hazards, preparedness, and recovery to a society, resulting in increasing preparedness and facilitating recovery (Wenger and Friedman 1986). The nature of subjects covered by the media across the four phases is distinct (PérezLugo 2004). Through crisis management analysis (e.g., (Okada and Ui 1997; Peterson 1988; Ishimine 2016; Tajima 2017)) and content analysis of news coverage during volcanic crises (e.g., (Harris et al. 2012; Harris 2015a; Harris 2015b; Harris and Villeneuve 2018a; Harris and Villeneuve 2018b; Calabró et al. 2020)), features and challenges about volcanic risk communication have been studied. However, from a long-term perspective (i.e., recovery and mitigation phases), few studies have investigated which issues regarding volcanic risk are covered by the media. In this study, we were interested in coverage of the recovery and mitigation phases. Recovery and mitigation operations restore the community, promote a return to (new) normal functions, and address future disasters. Through their coverage of disasters, media are considered disaster prevention information providers, which supposedly helps the community to raise disaster awareness, prepare for future events, and strengthen community resilience to disasters (Rodríguez 1997; Quarantelli 1996). With regard to seismic risks, Tekeli-Yesil et al. (2019) examined the features of seismic risk information provided by Turkish newspapers, and found that while there was significant coverage immediately after earthquakes, there was little news about earthquake disaster prevention. As a result, the printed media failed to play a central role in communicating appropriate risk information.

Japanese newspapers can be classified as local, regional, or national (Japan Visitor.com 2020). National newspapers circulate throughout the country; their headquarters are located in big cities such as Tokyo and Osaka. Conversely, regional and local newspapers are restricted to limited residential zones, and work significantly on local occurrences (Tekeli-Yesil et al. 2019; Jenkins and Nielsen 
2020). The victims of the 2014 Mt. Ontake eruption were tourists, and direct damage (such as from volcanic ash) did not take place in the residential areas around Mt. Ontake. As sudden, small-scale eruptions chiefly impact areas near a crater, tourists from big cities with opportunities to visit a crater are likely to get involved with a volcanic eruption disaster. In other words, although large eruptions which affect a wide area occasionally occur (e.g., the 1707 eruption of Mt. Fuji), most volcanic disasters are restricted to a specific geographical site. Consequently, such an event is less familiar to people living in big cities, compared to earthquakes and typhoons, and its risk may be poorly recognized (Cabinet Office 2017). Under such circumstances, national newspapers widely circulated in big cities tend to consider volcanic risk stories to have relatively lower news value. On the other hand, local newspapers based in communities with volcanoes, give volcanic risk news a higher value, because such calamities directly threaten residents' lives. In fact, Harris (2018) suggested that well-informed journalism was mostly practiced by local tabloids during the April 2007 eruption of Piton de la Fournaise (Harris and Villeneuve 2018a). To make society more resilient to volcanic crises, a social system in which Japanese society as a whole has a common understanding of volcanic risk should be built. However, the media's provision of different types information to different social strata results in an information gap about volcanic risk. Based on this background, the three types of newspapers are likely to frame volcanic disaster prevention and potential volcanic risk in different ways, aiming to make their stories appealing to their readership (Harris 2015a). In this study, we quantitatively explored discrepancies among articles on the $2014 \mathrm{Mt}$. Ontake eruption. Our first research question is: How have Japanese newspaper media covered volcanic eruption threats in the context of the 2014 Mt. Ontake eruption, especially during its anniversary?

Nick (2012) noted that media rule out alternative ideas, while selected facts are embedded in people's everyday actions and understanding. Hence, an information gap can affect the active process of remembering, through which groups construct their sense of community. Less extensive coverage may engender an apathetic attitude toward volcanic risk in societies that have little to do with volcanoes. Comments posted on news websites serve as public communication tools in the digital age, allowing sociological researchers to analyze public views on disaster risk issues (Valaskivi et al. 2019; Yamada 2020), even though the opinions expressed might not be entirely representative of the population at large. Thus, our second research question is: What rational/emotional reactions are evoked on the Web by the anniversary coverage? Due to the limitations of available data, we analyzed comments posted on the fifth anniversary news articles published on the Yahoo News site. While the news value of commemoration decreases as time passes, as a social custom, it transiently enhances in units of five or ten years (Forrest 1993). The increased media attention on the fifth anniversary evoked public interest. We observed comments reflecting peoples' opinions and considerations of the 2014 Mt. Ontake eruption.

\section{Methods \\ Materials collection}

Our unit of analysis is an individual newspaper article. The research material comprised five national newspapers (the Asahi Shimbun, the Mainichi, the Nikkei, the Sankei Shimbun, and the Yomiuri Shimbun), one regional newspaper published in the Chubu region in the central part of Japan (the Chunichi Shimbun), and one local newspaper based predominantly in Nagano Prefecture (the ShinanoMainichi Shimbun). The five national newspapers are mostly distributed in major Japanese cities. According to the Yomiuri Shimbun's media data (2019) (Yomiuri Shimbun 2019), the household penetration rate for these national newspapers exceeds $40 \%$ in Tokyo and Osaka. Although the overall circulation of national newspapers has fallen drastically since the rise of social networking sites (SNS), more than approximately 25 million copies are currently distributed nationwide. The percentages of the number of copies for respective newspapers are as follows: 39.6\% (Yomiuri), 28.2\% (Asahi), 13.4\% (Nikkei), 12.1\% (Mainichi), and 6.7\% (Sankei) (Yomiuri Shimbun 2019). The Chunichi Shimbun is the key regional newspaper of the Chubu area, in which Aichi Prefecture is home to Japan's fourth-largest city, with 7.5 million residents (Aichi Prefecture 2018); its household penetration rate is approximately $42 \%$, and its circulation amounts to approximately 1.4 million copies in Aichi Prefecture (Yomiuri Shimbun 2019). It is more popular than the national newspapers in the Chubu area. The Shinano-Mainichi Shimbun is a local newspaper in Nagano Prefecture (the home of Mt. Ontake); its household penetration rate is more than $50 \%$. Moreover, it has enthusiastically covered various topics related to the $2014 \mathrm{Mt}$. Ontake eruption through features such as serialized articles.

We obtained news articles on the $2014 \mathrm{Mt}$. Ontake eruption from an individual database, using the search terms "Mt. Ontake" and "eruption" from July 1, 2015, to October 30,2019 . Immediately after the eruption, the volcanic alert level, designated by the JMA, was raised from 1 to 3 , meaning that people should not approach within $4 \mathrm{~km}$ of the crater. In January 2015, the restricted area around the crater was reduced from $4 \mathrm{~km}$ to $3 \mathrm{~km}$, although the alert level was unchanged. The alert level was subsequently lowered to level 2 on June 26, 2015 (Japan Meteorological Agency 2018), as the JMA judged that the possibility of an eruption had declined (see Table 1). Here, we assumed that the change in the eruption alert level has a larger 
impact on the public risk perception than the change in access restrictions for dangerous areas because the alert level itself plays the role of a safety message. This lowered media attention on the $2014 \mathrm{Mt}$. Ontake eruption. Therefore, we selected a search period of July 1, 2015, to October 30, 2019.

We included articles that contained the search terms in the news item title because they made outstanding references to the 2014 Mt. Ontake eruption. For articles where the search terms did not appear in the title, but only in the news text, we identified eligible articles using the following procedure. We created a list of the top 20 most frequent words from the sample, which contained the search terms in the news item title. Subsequently, we calculated the average percentage of the top 20 words in the texts (frequencies divided by frequencies of all words). When an article without the search terms in its title had a larger number of the top 20 words than the average, it was deemed eligible for analysis, as we expected it to present stories on volcanic eruptions. It must be noted that articles in the local pages of national newspapers, which are circulated only in a limited area, were excluded. We filtered out articles with less than 250 characters because we considered their content to be thin. The sum of characters in articles with 250 characters or less was a tiny fraction of the total number of characters in samples. Therefore, this cutoff rule had little effect on our findings. Finally, we identified 2793 articles (Asahi, $n=123$; Yomiuri, $n=130$; Mainichi, $n=147$; Nikkei, $n=128$; Sankei, $n=117$; Chunichi, $n=683$; Shinano-Mainichi, $n=1465$ ) for analysis. Hereafter, the five national newspapers (Asahi, Yomiuri, Mainichi, Nikkei, and Sankei) were handled collectively as national newspapers. In addition, we termed the number of characters in the articles the "information volume."

To understand public responses to the fifth anniversary coverage of the $2014 \mathrm{Mt}$. Ontake eruption, we scrutinized comments posted on Yahoo News, which is the most popular online news portal in Japan (Kiyohara et al. 2018), and reaches approximately half (52\%) of the country's online news readers each week (Reuters Institute 2019). Yahoo's message posting service for news reports is one of the most popular communication platforms. We distinguished arguments shared by online news readers. We found three online news items referring to the 2014 Mt. Ontake eruption during September 2019, which were termed News A, News B, and News C. We collected comments posted on Yahoo News nearly three days after the news reports were published. Consequently, the total number of comments amounted to 627 , of which 66, 137, and 424 were posted in response to News A, B, and C, respectively. Since we gathered the comments a considerable time after the articles were published, the number of comments did not change drastically following sample collection. The average and median numbers of words per comment in the sample were 56 and 40, respectively, on the basis of adjectives, adverbs, verbs, and nouns. Comments with a smaller number of words than the first quartile point ( 20 words) were regarded as thin content, and were removed from the sample data, culminating in 469 eligible comments. We considered that the discourses on online comments would be sensitive to the articles' arguments. Although the number of stories was limited, our content analysis of the online comments enhanced our understanding of public responses to the anniversary coverage.

\section{Unsupervised text classification}

We subjected the texts of the entire sample to morphological analyses using KH Coder (Higuchi 2016) (a free software package for text mining) which allowed us to generate word frequency lists and co-occurrence network maps (Higuchi 2017), and Mecab (Kudo et al. 2004) (an open source text segmentation library for texts written in Japanese). By applying a bag-of-words model, we can encode a text as a feature vector and obtain the frequency of each word (Yamada 2017). In addition, we calculated word importance weights using Term Frequency-Inverse Document Frequency (TF-IDF) (Büettcher et al. 2010) for individual words, using the Python program (Kawahara 2020). With the development of deep learning approaches, ample progress has been made in automatic text categorization. Computer-assisted content analysis is becoming a popular method for extracting structured data from unstructured text (Aaldering and Vliegenthart 2016; Neuman et al. 2014; Damstra et al. 2019). Automatic text categorization, with clear rules and algorithms, helps researchers classify texts into a certain number of predefined categories (Le-Khac et al. 2010). We categorized news articles by grouping the vectors that represent texts (Liu and Lu 2018; Yamada 2019). We created the distributed representations of each text using the Paragraph Vector model, an unsupervised method that learns continuous distributed vector representations for pieces of text (Le and Mikolov 2014).

Determining the most appropriate number of clusters in a given dataset is known as the cluster validation problem, and there are plenty of studies (e.g., (Milligan and Cooper 1985; Aggarwal and Reddy 2013; Patil and Baidari 2019)). We used the average silhouette technique (Rousseeuw 1987) and slope method (Fujita et al. 2014) to determine the optimal number of clusters. These correspond to nonparametric approaches. The cluster number examined varied from 4 to 20 .

We utilized the Doc2Vec class from the Gensim library (Řehưrek and Sojka 2010), which is one of the implementations of Paragraph Vector. For the average silhouette technique and the slope method, we used the Analysis 
of Cluster Variability (ANOCVA) package (Version 0.1.1), implemented in R (Vidal and Fujita 2017). We set the values for other parameters such as the minimum count of words and the window size as 10 and 15, with reference to a previous study (Lau and Baldwin 2016). As for the text vector size, we changed it from 50 to 500 in increments of 50 and calculated the text vector for each parameter. Finally, we applied the text vectors to the Silhouette technique and the slope method to determine the optimal number of clusters. In this study, the size of the text vectors was determined as 150 , so that the cluster numbers estimated by the two methods coincided.

\section{Results}

\section{Primary themes within the articles}

First, in order to look at the trends of media attention for national, regional, and local newspapers, we gauged media attention by the monthly number of characters in articles. Figure 2 illustrates the time series of the percentage of information volume in articles published each month. We labeled September and October as "anniversary months," since the Mt. Ontake eruption occurred on September 27,2014 , although news stories concerning volcanic eruptions were quite apparent in September. Months other than September or October are "ordinary months."

The time series of media attention was almost similar, and peak months coincided with anniversary months, resulting in a constant amount of coverage, comprising approximately $8 \%$ of the total information volume each year. Figure 2 also shows a small quantity of information volume during each ordinary month. National newspapers had a larger amount of coverage in the first anniversary year, peaking in January 2018, which corresponds to the volcanic eruption of Mt. Kusatsu-Shirane, where one person was killed and dozens of skiers were injured (see Table 1). The ratios of the information volumes in anniversary months compared to the total were $44.6 \%, 46.3 \%$, and $41.1 \%$ for national, regional, and local newspapers, respectively. These temporal trends of media attention are in line with those of previous studies (Trümper and Broer 2019; Valaskivi et al. 2019).

The automatic text categorization revealed that 2793 news articles from seven newspapers could be grouped into five clusters (categories). Table 2 presents a list of the top 10 most important words for each cluster. Table 3 provides the summary statistics of each cluster. The number of sample months is 52 , and that of the anniversary month is 10. If the information volume is equal in all months, $N_{\mathrm{a}} / N$ is approximately 0.2 , where $N_{\mathrm{a}}$ is the information volume in anniversary months and $N$ is the total information volume. From Table 3, Additional file 1 depicts the relationship between $N_{\mathrm{c}} / N$ and $N_{\mathrm{ca}} / N_{\mathrm{c}}$ for each cluster of national, regional, local, and all newspapers, where $N_{\mathrm{c}}$ and $N_{\text {ca }}$ correspond to the information volume of each cluster and that in the anniversary months. As seen in Table 3 , the $N_{\mathrm{ca}} / N_{\mathrm{c}}$ of clusters 1 and 3 was larger than 0.4 ; we labeled them as the anniversary clusters. A cluster with $N_{\text {ca }} / N_{\mathrm{c}}>0.4$ means that it had a large amount of coverage in anniversary months.

The national and regional media focused on one or two topics. The topics of clusters 1 and 2 were important for national and regional newspapers, respectively. On the other hand, local media covered four topics evenly. The Spearman's rank correlation coefficients, which measures

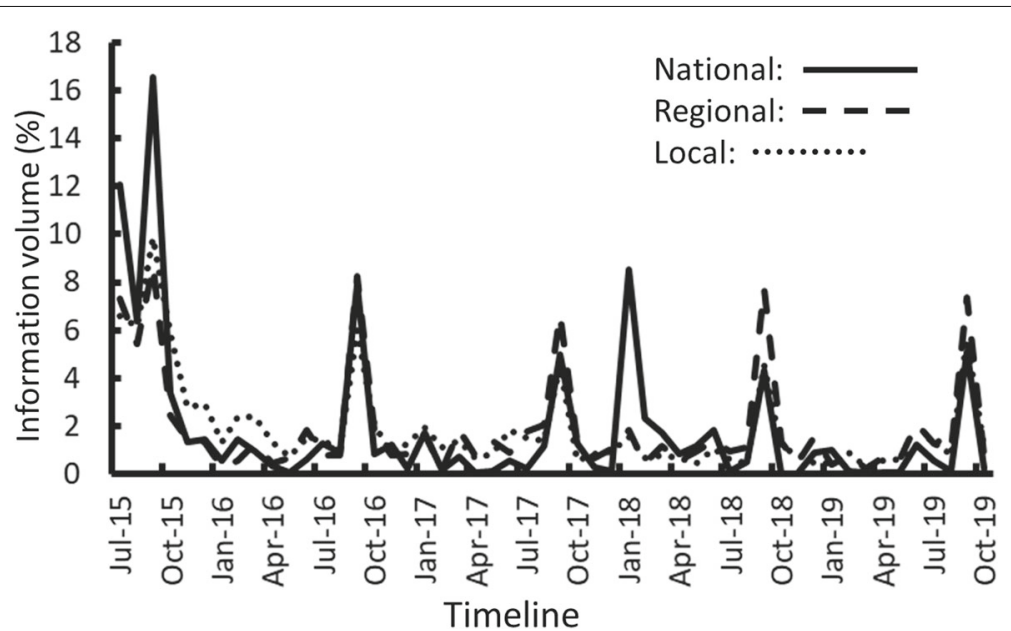

Fig. 2 Monthly temporal profiles of the percentage of information volume for each month. The solid, dashed, and dotted lines respectively represent the time series for the national newspapers (the Asahi Shimbun, the Mainichi, the Nikkei, the Sankei Shimbun, and the Yomiuri Shimbun), the regional newspaper (the Chunichi Shimbun), and the local newspaper (the Shinano-Mainichi Shimbun). We defined the information volume as the sum of characters of news articles published in a month. The total number of characters contained in the samples were 553148,479479 , and 1020193 for the national, regional, and local newspapers, respectively 
Table 2 List of the topic labels and the top 10 most important words from the term frequency-inverse document frequency (TF-IDF) for each cluster

\begin{tabular}{|c|c|c|}
\hline Cluster \# & Top 10 words & Topic label \\
\hline 1 (anniversary) & $\begin{array}{l}\text { regulation, } \\
\text { mountaineering, lift a } \\
\text { warning, Otaki (place } \\
\text { name), village, tourism, a } \\
\text { mountain cabin, summit, } \\
\text { investigation, town }\end{array}$ & $\begin{array}{l}\text { Mt. Ontake's volcanic } \\
\text { warning status }\end{array}$ \\
\hline 2 & $\begin{array}{l}\text { evacuation, plan, research, } \\
\text { (warning) level, prefecture, } \\
\text { the bereaved, disaster } \\
\text { prevention, municipality, } \\
\text { earthquake, Kusatsu (place } \\
\text { name) }\end{array}$ & $\begin{array}{l}\text { Municipalities' } \\
\text { volcanic emergency } \\
\text { plans }\end{array}$ \\
\hline 3 (anniversary) & $\begin{array}{l}\text { search, commemoration, } \\
\text { volcano, regulation, Otaki } \\
\text { (place name), the } \\
\text { bereaved, photo, eulogy, } \\
\text { disclosure, Nagano (place } \\
\text { name) }\end{array}$ & Human interest \\
\hline 4 & $\begin{array}{l}\text { (Mt. Ontake Volcano) } \\
\text { Meister, Kiso (place name), } \\
\text { climbing, prefecture, } \\
\text { (evacuation) shelter, } \\
\text { research, disaster } \\
\text { prevention, consider, plan, } \\
\text { evacuation }\end{array}$ & $\begin{array}{l}\text { Lessons learned from } \\
\text { the } 2014 \text { Mt. Ontake } \\
\text { eruption }\end{array}$ \\
\hline 5 & $\begin{array}{l}\text { advance team, shelters, } \\
\text { investigation, Gifu (place } \\
\text { name), Nagano (place } \\
\text { name), establish (a task } \\
\text { force), volcano, family, a } \\
\text { prefectural governor, send } \\
\text { (a rescue team) }\end{array}$ & $\begin{array}{l}\text { Searching for missing } \\
\text { persons }\end{array}$ \\
\hline
\end{tabular}

The first column shows the cluster number (\#). The label "anniversary" indicates that there was a lot of coverage during an anniversary month. "Top 10 most important words" means the ten highest keywords, weighted by their TF-IDF for each cluster the strength and direction of association between two ranked variables (Laed.com 2020), of the information volume for each cluster between the three newspaper forms in Table 3 were 0.3 (national vs. Chunichi), 0.7 (national vs. Shinano-Mainichi), and 0.7 (Chunichi vs. Shinano-Mainichi), respectively. The low correlation value (Mukaka 2012) between the regional and national newspapers indicates that the attention pattern of each media differed considerably. Further, the correlation coefficients among the five national newspapers were higher than 0.7. We concluded that the five national media had similar trends in their coverage.

\section{Cluster 1 topic (anniversary cluster): "Mt. Ontake's volcanic warning status"}

Cluster 1, which had the largest information volume, contained terms related to official warnings or regulations issued by the JMA for Mt. Ontake, such as "regulation," "mountaineering," and "lift a warning" (see Table 2). We categorized this as an anniversary cluster. The number of articles attributed to this cluster was 94, 284, and 486 for national, regional, and local newspapers, respectively. For the regional and local newspapers, the information volume of Cluster 1 corresponded to $40 \%$ and $30 \%$ of the total information volumes, whereas it occupied $10 \%$ for national newspapers. Regional and local media primarily covered this topic. To probe the relationship between words with high word importance, we utilized a cooccurrence network of high-frequency words in which the interactions between words with similar appearance patterns were connected by links (Drieger 2013; Borgatti 2005). Understanding the patterns of connections between words enabled us to discern the semantic meanings of groups of words. Figure 3 (a) displays the cooccurrence network diagram for Cluster 1. Networks with a small number of nodes are not plotted in Fig. 3a. We

Table 3 Summary statistics

\begin{tabular}{|c|c|c|c|c|c|c|c|c|}
\hline \multirow{2}{*}{ Cluster \# } & \multicolumn{4}{|l|}{$N_{\mathrm{c}}$} & \multicolumn{4}{|c|}{$N_{\mathrm{ca}} / N_{\mathrm{c}}$} \\
\hline & All & National & Regional & Local & All & National & Regional & Local \\
\hline 1 (anniversary) & $\begin{array}{l}570488 \\
(27.8 \%)\end{array}$ & $\begin{array}{l}56198 \\
(10.2 \%)\end{array}$ & $\begin{array}{l}196143 \\
(40.9 \%)\end{array}$ & $\begin{array}{l}318147 \\
(31.2 \%)\end{array}$ & 0.457 & 0.551 & 0.491 & 0.420 \\
\hline 2 & $\begin{array}{l}542768 \\
(26.4 \%)\end{array}$ & $\begin{array}{l}261569 \\
(47.3 \%)\end{array}$ & $\begin{array}{l}58233 \\
(12.1 \%)\end{array}$ & $\begin{array}{l}222966 \\
(21.9 \%)\end{array}$ & 0.340 & 0.364 & 0.340 & 0.312 \\
\hline 3 (anniversary) & $\begin{array}{l}494017 \\
(24.1 \%)\end{array}$ & $\begin{array}{l}152135 \\
(27.5 \%)\end{array}$ & $\begin{array}{l}123673 \\
(25.8 \%)\end{array}$ & $\begin{array}{l}218209 \\
(21.4 \%)\end{array}$ & 0.629 & 0.692 & 0.637 & 0.580 \\
\hline 4 & $\begin{array}{l}330112 \\
(16.1 \%)\end{array}$ & $\begin{array}{l}52335 \\
(9.5 \%)\end{array}$ & $\begin{array}{l}74019 \\
(15.4 \%)\end{array}$ & $\begin{array}{l}203758 \\
(20.0 \%)\end{array}$ & 0.386 & 0.293 & 0.353 & 0.421 \\
\hline 5 & $\begin{array}{l}115435 \\
(5.6 \%)\end{array}$ & $\begin{array}{l}30911 \\
(5.6 \%)\end{array}$ & $\begin{array}{l}27411 \\
(5.7 \%)\end{array}$ & $\begin{array}{l}57113 \\
(5.6 \%)\end{array}$ & 0.038 & 0.000 & 0.041 & 0.057 \\
\hline
\end{tabular}

$N_{c}$ represents the total number of characters for each cluster, while $N_{c a}$ indicates the number of characters in articles published during anniversary months. The percentages of $N_{c}$ to $N$ (whereby $N$ corresponds to the total number of characters) for each cluster of each newspaper type are indicated in parentheses. The label "all," denotes all newspapers. The labels "national," "regional," and "local" comprise the national ones (the Asahi Shimbun, the Mainichi, the Nikkei, the Sankei Shimbun, and the Yomiuri Shimbun), the regional one (the Chunichi Shimbun), and the local one (the Shinano-Mainichi Shimbun), respectively 

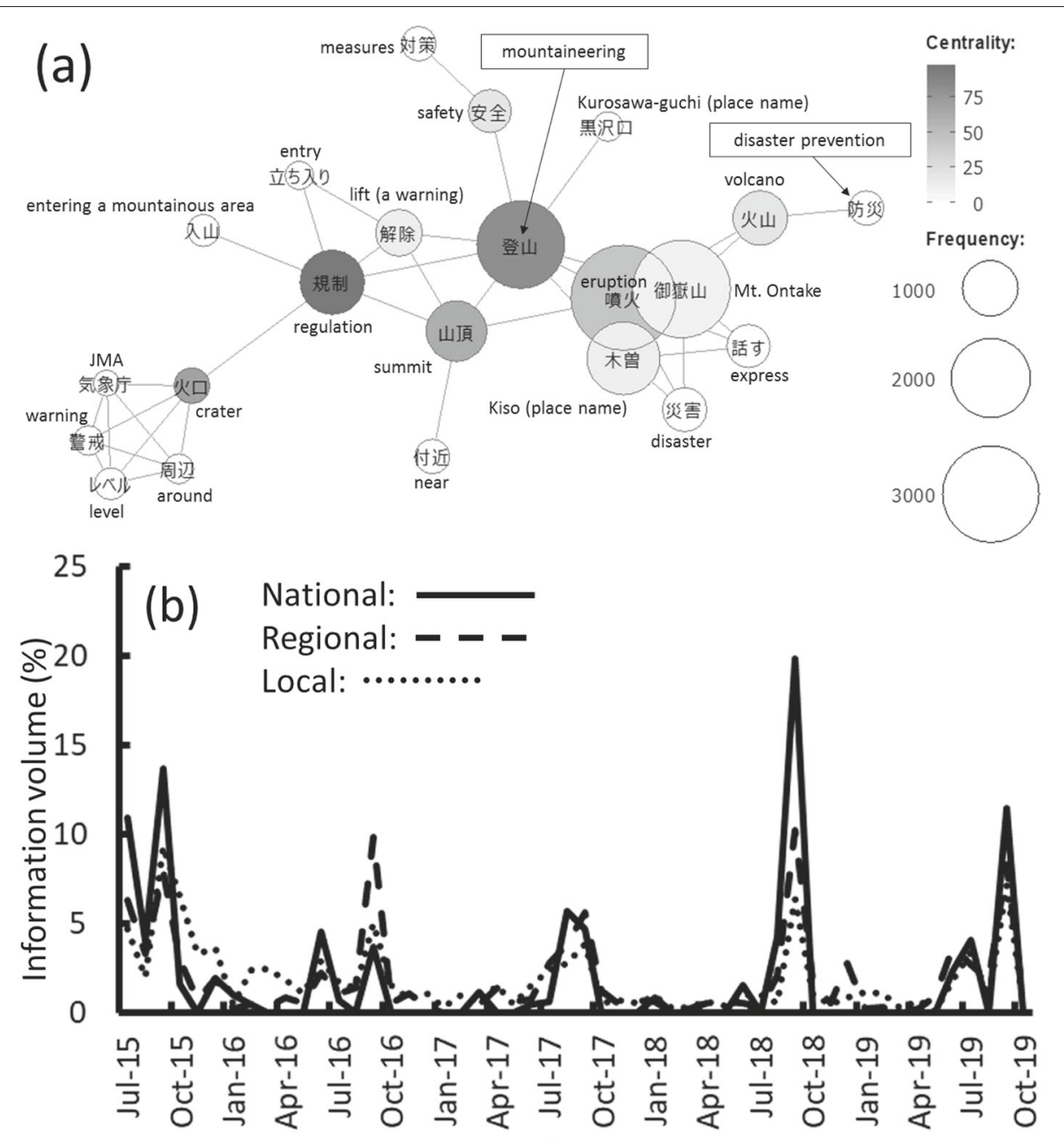

Timeline

Fig. 3 a Network visualization of words contained in the articles belonging to Cluster 1. Nodes (words) with the highest betweenness centrality are darker on the graph. A node with a large betweenness centrality corresponds to the point through which the route passes many times when each node is connected by the shortest path (Kadoguchi 2015). Each node's size (circle size) is proportional to its frequency. Links between words are created according to a cosine similarity greater than 0.50 . Nodes are automatically arranged, and the superimpositions between nodes indicates a link. b Monthly variations in the percentage of information volume for Cluster 1. The solid, dashed, and dotted lines represent the information volume for national, regional, and local newspapers, respectively. It is noted that the information volume corresponded to the sum of characters of news articles in a month

conducted a network analysis of words for all articles belonging to this cluster. A word with higher betweenness centrality is usually called a hub or highly central (Buckner et al. 2009), as other words will be connected through it. That is to say, the word with the highest betweenness centrality will likely appear in the same text as a keyword. This network points to stories that referred to the volcanic alert level. In addition, Fig. $3 \mathrm{~b}$ shows the time series of the percentage of the information volume in each month for national, regional, and local newspapers. These peaks corresponded to months when volcanic warnings were deregulated (see Table 1). We inferred that the articles in Cluster 1 comprised news stories related to volcanic warnings about Mt. Ontake. We defined articles that included the highest ratio of the top 10 most important words, as shown in Table 2, compared to the total number of words, as representative samples of Cluster 1. Table 4 provides a list of their titles.

\section{Cluster 2 topic: "Municipalities' volcanic emergency plans"}

In Cluster 2, terms such as "evacuation," "plan," and "warning level" had high TF-IDF values (see Table 2). The number of articles attributed to this cluster was 253, 69, and 302 for national, regional, and local newspapers, respectively. Figure 4a shows the largest co-occurrence network diagram for Cluster 2. As displayed in Table 4 
Table 4 Example titles of four representative articles for each cluster

\section{Cluster \#}

1 (anniversary)
3 (anniversary)

\section{Examples of article titles}

- Ontake area in the summer, climbing season on the side of the town of Kiso, removal of a warning alert. (Y, July 2, 2019)

— To climb Mt. Ontake, regulations will again be established, starting today. (C, October 8, 2018)

- A warning alert for part of the Kurosawa-guchi route at Mt. Ontake's ninth station will be removed today. (C, June 28, 2016)

- The town of Kiso decided to remove a warning alert for the Mt. Ontake trail from July 1 to October 16. (Sh, March 7, 2019)

— Volcanic eruption of Mt. Kusatsu-Shirane. Imperfect volcano evacuation plan in most towns, including Kusatsu-machi, Gunma. (M, January 26, 2018)

- There was a phreatic eruption at Mt. Kusatsu-Shirane. Evacuation plans are inadequate in two-thirds of all municipalities in volcanic areas. Kusatsu-machi was also undecided. Obligations have not been firmly followed. (N, January 25, 2018)

- Volcanic evacuation plans are created in 51 municipalities, and two-thirds of all plans are being considered. (C, June 24, 2017)

- Thirty percent of the municipalities in volcanic zones have produced volcanic evacuation plans. Many municipalities have been unable to keep up with the revised law. (A, January 28, 2018)

- Bereaved families completed a memorial climb on Mt. Ontake and commemorated the victims of the eruption. (N, July 24, 2017)

- The second anniversary of the Mt. Ontake eruption. Grieving families requested that a tombstone be built for the victims at a commemorative ceremony site. (Sh, September 28, 2016)

- The unveiling of the tombstone for the victims was conducted in the village of Otaki in Nagano Prefecture. (A, September 27, 2017)

- The Mt. Ontake executive committee that built the tombstone was dissolved. (Sh, June 27, 2019)

- The town of Kiso created an evacuation plan and added it to the Kiso's disaster prevention plan. This is due to the obligation of the revised Act on Special Measures Concerning Active Volcanoes. (C, October 2, 2018)

- Nagano Prefecture announced the revised Nagano's disaster prevention plan this year. The Volcanic Disaster Council's role was stipulated. (Sh, December 23, 2015)

- The town of Kiso designed an evacuation plan in the case of an eruption. (Sh, October 3, 2018)

- The Mt. Ontake Volcanic Disaster Council decided to work out detailed evacuation and guidance procedures for hikers when the action plan was revised in FY2017. (Sh, March 22, 2017)

- An advanced team will go to Mt. Ontake tomorrow. (C, July 11, 2015)

- The volcanic eruption of Mt. Ontake. An advanced team will be sent tomorrow, Nagano-Gifu. (M, July 11, 2015)

- The volcanic eruption of Mt. Ontake. An advanced team will re-investigate tomorrow, and 44 members will be sent. Press release from the prefecture's disaster countermeasures office. (Sh, July 11, 2015)

- To resume the search for missing persons, an advanced team will be sent to the summit of Mt. Ontake starting on July 7. (C, July 4, 2015) 

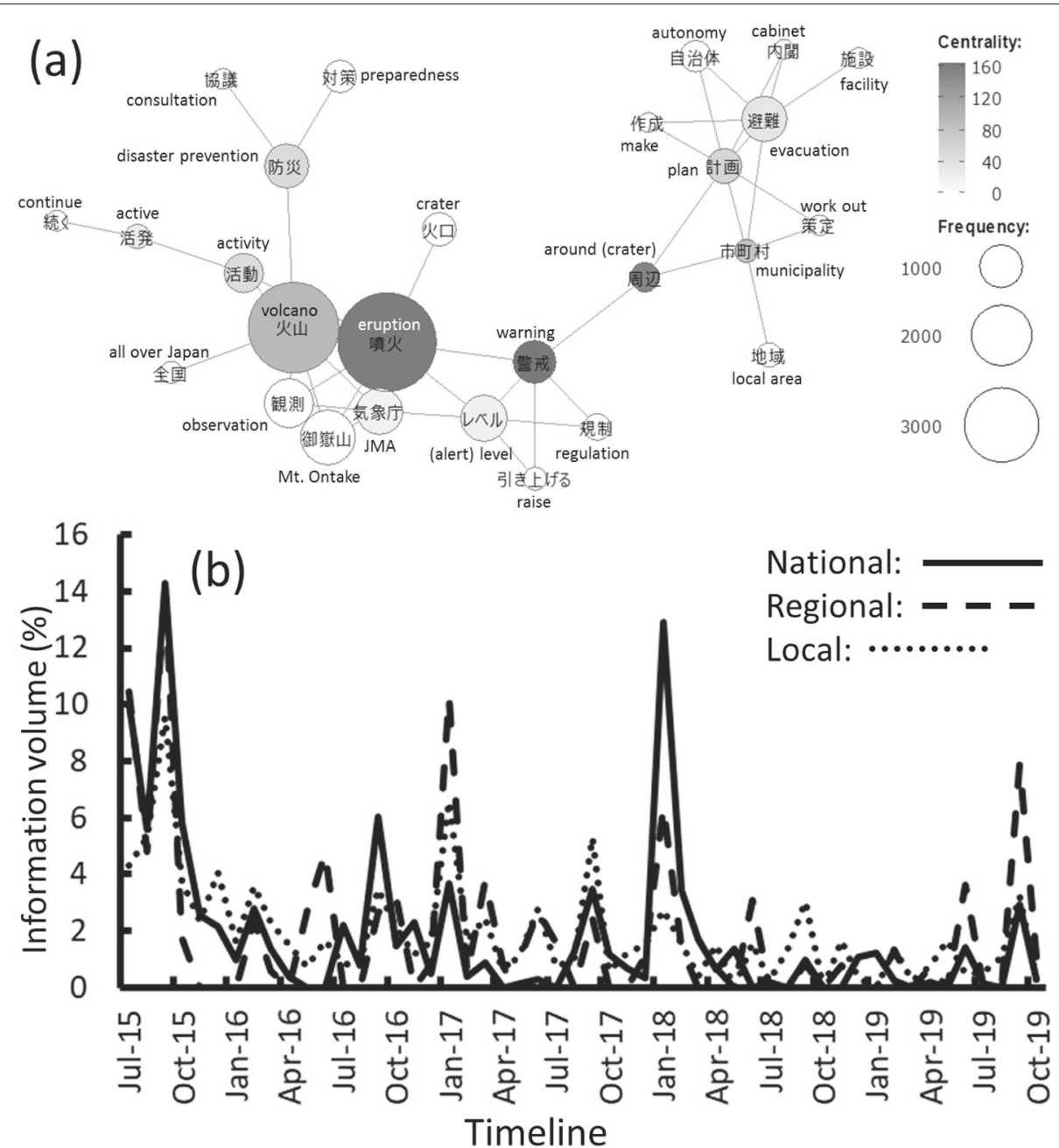

Fig. 4 The same as Fig. 3, but for Cluster 2. In panel (a), links between words are created according to a cosine similarity larger than 0.56

and the network in Fig. 4a, political stories about the development of municipal volcanic emergency plans were mostly centered. The time series of the degree of the information volume in each month are presented in Fig. $4 \mathrm{~b}$ for national, regional, and local newspapers, respectively. National newspapers focused on this topic in relation to the 2018 Kusatsu-Shirane volcanic eruption. As outlined in Table 3, national newspapers pointed significantly to municipalities' volcanic emergency plans or programs and contained nearly half of the total information volumes, as this political topic was associated with a wide readership. There were many articles pointing out the delay in the development of municipal volcanic emergency plans (see Table 4). Moreover, as mentioned below in detail, the subject regarding the legal action against the local government and the JMA brought by the bereaved was also included. Media framing plays a key role in communicating forecast and uncertainty regarding a volcanic eruption (Harris 2015a; Harris 2015b). A negative frame may cause people to feel disappointed with the government administrations and experts responsible for volcanic risk management.

\section{Cluster 3 topic (anniversary cluster): "Human interest"}

The number of articles attributed to this cluster was 192, 156, and 306 for national, regional, and local newspapers, respectively. The higher TF-IDF words in Cluster 3 were "commemoration," "the bereaved," and "eulogy" (see Table 2), and Cluster 3 had a network in which these terms were linked to each other, as depicted in Fig. 5a. The titles in Table 4 indicate that this cluster included many human interest stories of the bereaved. From Table 3 and the time series of Fig. 5b, all newspapers picked up the topic of Cluster 3 in the anniversary months and had the highest $N_{\mathrm{ca}} / N_{\mathrm{c}}$. The proportion of information volume for national and regional newspapers was higher than $25 \%$. 

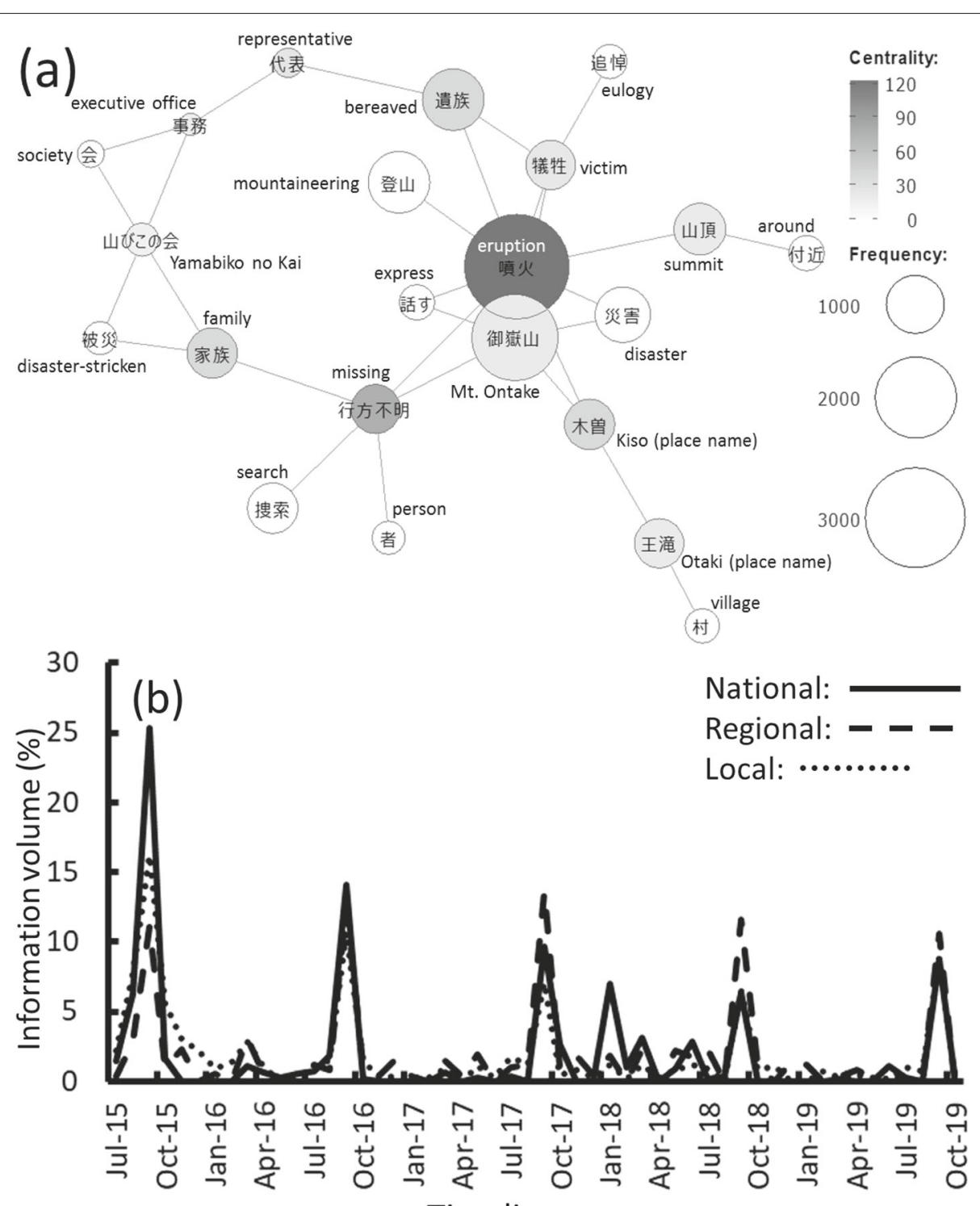

Timeline

Fig. 5 The same as Fig. 3, but for Cluster 3. In panel (a), links between words are created according to a cosine similarity larger than 0.55. In panel (a), "Yamabiko no Kai" is the group name for the families of victims of the 2014 Mt. Ontake eruption

They focused on human interest stories, as most of the victims of the volcanic eruption were tourists from various big cities.

\section{Cluster 4 topic: "Lessons learned from the 2014 Mt. Ontake eruption"}

Cluster 4 contained keywords pertaining to volcanic disaster prevention (Table 2). The number of articles attributed to this cluster was 53, 129, and 284 for national, regional, and local newspapers, respectively. As seen in Fig. 6a, terms regarding regionality ("Mt. Ontake," "Kiso," "prefecture") are located in the network's center. Based on lessons learned from the 2014 volcanic disaster, Nagano Prefecture launched a certification system called the "Mt. Ontake Volcano Meister" in 2018 to train people to effectively disseminate knowledge on volcanic disaster prevention and natural beauty around the Kiso region including Mt. Ontake (see Fig. 1) (Nagano Prefecture 2017). Local media attention was most plentiful among the three newspaper types because this topic was more connected with local territory. The temporal variation in Fig. $6 \mathrm{~b}$ appeared to be less sensitive to the anniversary months, although the number of articles gradually declined. For national newspapers, temporal variation seemed to differ from the other two types because the matter may have only caught the attention 

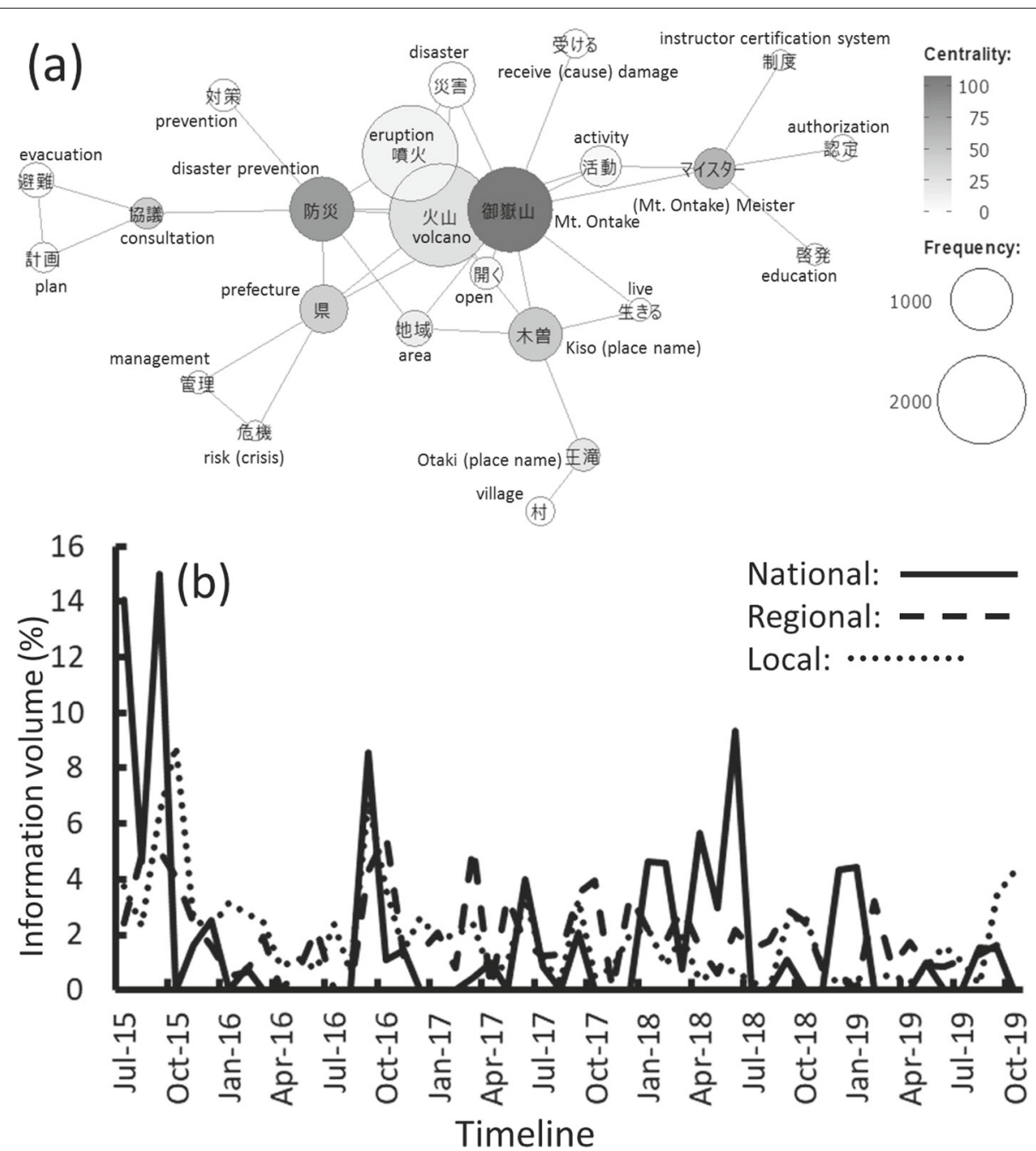

Fig. 6 The same as Fig. 3, but for Cluster 4. In panel (a), links between words are created according to a cosine similarity larger than 0.49

of journalists from national newspapers when distributing press releases. Conversely, local media were able to continuously track various activities to support disaster prevention and mitigation efforts.

\section{Cluster 5 topic: "Searching for missing persons"}

The information volume in Cluster 5 was the smallest of all clusters (Table 3). The number of articles attributed to this cluster was 53, 45, and 87 for national, regional, and local newspapers, respectively. The co-occurrence network diagram and the time series of the information volume for Cluster 5 are given in Additional file 2 . The co-occurrence network diagram for Cluster 5 contained terms such as "search," "missing persons," "(rescue) member," and "resuming activities." The time series of the degree of the information volume for national, regional, and local newspapers only portrayed articles published in July and August 2015. Almost no reports appeared after that period. The stories belonging to Cluster 5 referred to the news topic of searching for missing persons (see Tables 1 and 4).

\section{The priority of each cluster in the media sphere}

Articles on a front page attract many people's attention (Harris and Villeneuve 2018b). News topics deemed most important by a newsroom appear on the front page. The amount of information volume of each cluster on the front page is shown in Table 5. For national newspapers, Clusters 2 and 3 appeared on the front page. This

distribution was consistent with that shown in Table 3. The regional newspaper had more human stories belonging to Cluster 3 on the front page which accounted for $40 \%$ of the total. For the local newspaper, the amount of information volume of Clusters 1, 2, and 3 was in the $20 \%$ range, followed by Cluster $4(15 \%)$. The ratios of the information volume on the front page to the total 
Table 5 The amount of the information volume of articles published on the front page

\begin{tabular}{llll}
\hline Cluster \# & National & Regional & Local \\
\hline 1 (anniversary) & $1999(7.9 \%)$ & $8536(26.8 \%)$ & $32750(25.0 \%)$ \\
2 & $13683(54.2 \%)$ & $5443(17.1 \%)$ & $30713(23.4 \%)$ \\
3 (anniversary) & $6409(25.4 \%)$ & $12056(37.9 \%)$ & $34705(26.4 \%)$ \\
4 & $396(1.6 \%)$ & $1715(5.4 \%)$ & $19974(15.2 \%)$ \\
5 & $2750(10.9 \%)$ & $4062(12.8 \%)$ & $13119(10.0 \%)$ \\
\hline
\end{tabular}

In parentheses, the percentage of the information volume for each cluster of respective newspaper types is indicated

were $4.6 \%$ for national newspapers, $6.6 \%$ for the regional newspaper, and $12.9 \%$ for the local newspaper. This indicates that, quantitatively, the local newspaper became an important source in terms of the volcanic risk communication, and this result is consistent with the coverage slant of regional reporting agencies during the eruption of Stromboli (Calabró et al. 2020).

\section{Media attention to the lawsuit brought against the local government and the JMA}

As shown in Table 1, Mt. Ontake is an active volcano (Japan Meteorological Agency 2020). While volcanic earthquakes occurred frequently in early September 2014, the JMA decided not to raise the eruption alert level at that time. A group of the bereaved filed a lawsuit in January 2017, claiming that this decision was wrong. This issue raises an opportunity to think about what the eruption warning system, linked to eruption predictability, means for the society, and how we should take advantage of it. Here, we examined how substantial attention media paid to this trial. We considered articles containing "trial/suit/lawsuit" in their titles as articles that mainly reported on trial-related topics, and extracted these from the sample data. Table 6 shows the distribution of the information volumes for each cluster. As shown in Table 6, the trial-related articles mainly belonged to Cluster 2 . The information volumes for national, regional, and local newspapers correspond to approximately $4 \%, 30 \%$, and $15 \%$, respectively. In the case of national newspapers, trialrelated articles have not appeared on general pages (e.g., social or political pages) since 2018. On the other hand, the regional and local newspapers had several followup articles in 2018 and 2019 (six articles in 2018 and two articles in 2019 were found in the regional newspaper; seven articles in 2018 and three articles in 2019 in the local newspaper). National newspapers regarded this topic as minor news value. Readers of these newspaper could only understand the progress of this trial by obtaining information from other media.

Close reading of the texts showed that all the primary news articles mentioned how the bereaved felt and what claims they made in the court case, with subsequent articles referring to the trial progress. Here, we searched for articles containing the words "forecast/prediction" and "expert/researcher/university/professor" in their texts, and returned 0,3 , and 10 hits for national, regional, and local newspapers, respectively. National newspapers thus had no articles with "expert/researcher/university/professor." The regional and local newspapers reported on the predictability of the $2014 \mathrm{Mt}$. Ontake eruption as well as the general eruption predictability, citing comments from experts (see the word co-occurrence network in Additional file 3). Since the focus of the trial was how responsible it was for the JMA not to raise the eruption alert level when volcanic earthquakes increased at the beginning of September 2014, the expert's comments were quoted in line with this main point. We were not able to confirm any further development of this topic. The eruption predictability was presented in a way that a supplementary explanation of the trial was given.

\section{Public responses to the anniversary coverage}

We first examined the relationship between media attention and public interest. We utilized Google Trends to monitor the longitudinal progression of people's search

Table 6 Summary statistics for articles that contain "trial/suit/lawsuit" in their title

\begin{tabular}{|c|c|c|c|c|c|c|}
\hline \multirow{2}{*}{ Cluster \# } & \multicolumn{3}{|c|}{ (a) Article number } & \multicolumn{3}{|c|}{ (b) Information volume } \\
\hline & National & Regional & Local & National & Regional & Local \\
\hline 1 (anniversary) & 0 & 0 & 0 & 0 & 0 & 0 \\
\hline 2 & $\begin{array}{l}19 \\
(7.5 \%)\end{array}$ & $\begin{array}{l}24 \\
(34.8 \%)\end{array}$ & $\begin{array}{l}46 \\
(15.2 \%)\end{array}$ & $\begin{array}{l}10337 \\
(4 \%)\end{array}$ & 16931 (29.1\%) & $33690(15.1 \%)$ \\
\hline 3 (anniversary) & $1(0.5 \%)$ & 0 & $3(1 \%)$ & $\begin{array}{l}700 \\
(0.5 \%)\end{array}$ & 0 & $2771(1.3 \%)$ \\
\hline 4 & 0 & $1(0.8 \%)$ & $1(0.4 \%)$ & 0 & $949(1.3 \%)$ & $334(0.2 \%)$ \\
\hline 5 & 0 & 0 & 0 & 0 & 0 & 0 \\
\hline
\end{tabular}

The columns ( $a$ ) and (b) denote the number of articles and the information volume for national, regional, and local newspapers, respectively. The percentages of the value to the total for each cluster of each newspaper type are indicated in parentheses. The labels "national," "regional," and "local" denote the national newspapers, the regional newspaper, and the local newspaper, respectively 
activities (Yeo and Knox 2019). We extracted the time series data from the Google Trends site using the keyword "Mt. Ontake" between 2015 and 2019. The Pearson's correlation coefficients between the time series data of the search pattern and each newspaper, as seen in Fig. 2, were 0.77 for national newspapers, 0.78 for the regional newspaper, and 0.76 for the local newspaper, meaning that more intense coverage increased search activity. Taking the media agenda setting theory (Takeshita 2008) into account, the heavy media coverage during the anniversary months points to a salient perception of volcanic risk.

Subsequently, we closely explored the public discourse regarding the anniversary coverage of the 2014 Mt. Ontake eruption based on our content analysis of comments posted online. On Yahoo News, we identified three articles that mentioned the fifth anniversary of the 2014 volcanic disaster. Their titles were as follows:

- News A: "Keep Mt. Ontake in a safe place: Measures are being taken to protect a mountain cabin from ash deposits" (September 27, 2019, the Gifu Shimbun, 972 characters).

- News B: "Mt. Ontake, located on the border between Nagano and Gifu prefectures: Fifth anniversary of the volcanic hazard. At the foot of the mountain, bereaved families took part in a commemorative ceremony and offered silent prayers at 11:52 (the time of the eruption) Nagano" (September 27, 2019, Nagano Broadcasting Systems, Inc., 340 characters, transcript text).

- News C: "Fifth anniversary of the volcanic hazard. What is Mt. Ontake 'now?' The trails that many victims hiked are still off limits. A man with a missing son said this is regrettable" (September 27, 2019, Tokai Television Broadcasting Co., Ltd., 907 characters, transcript text).

News A was about ash deposit prevention measures for a mountain cabin on Mt. Ontake, and contained an interview with a mountain cabin worker. This article has the characteristics of Clusters 2 and 4. News B and News C were about bereaved families' feelings. We classified these articles under Cluster 3. The frame of each news report influenced the discourse of the comments. However, as three news articles had a common format of anniversary coverage, we thought that our findings could serve as a reference to understand how anniversary coverage affected readers' opinions.

We applied a quantitative approach to our content analysis of the 469 comments. Figure 7 shows a network visualization of the co-occurring terms. In this case, the components of the word vector for each text were basically made of 0 or 1 owing to short sentences. For a binary matrix, the Jaccard coefficient is an effective way to compute similarities between comments, in contrast to the cosine similarity (Aggarwal 2018). We obtained two networks with 15 and 8 words, respectively. The other networks were small. The largest network (Network 1) encompassed terms such as "mountaineering" and "nature," which had the highest betweenness. Connecting periphery terms included "at one's own risk," "disaster," "danger," and "human." The second largest network (Network 2) had a straight-line structure with "tax," "rescue," and "getting lost (in the mountains)" in the center. We determined the typical examples of comments in each network, as follows. We calculated the ratio of frequencies of Network X's terms in comment No. Y, compared to the product of the total frequencies of terms in comment No. $Y$ and the total number of Network X's terms, where $\mathrm{X}$ is the network ID and $\mathrm{Y}$ is the comment ID. We deemed several comments with a larger ratio to be representatives of Network X. These are presented in Table 7.

As seen in Fig. 7 and Table 7, comments belonging to Network 1 insisted that people should climb a mountain at their own risk because a volcano is dangerous, or because human beings are powerless before nature. Comments in Network 2 contended that taxpayers need not fund operations to rescue climbers stranded on a mountain, as mountaineering is a leisure activity. In Network 2, many comments argued about the misallocation of public funds, while a small number advocated for spending tax money to perform rescue efforts. In this case, many comments were posted on human interest reports, especially News C (67.2\% of all eligible comments). Hence, people likely looked at the emotional impact of volcanic disasters on survivors, rather than aspects concerning prevention and mitigation. The opinion that volcanic risk should be attributed to a single individual might originate from the idea that volcanic risk does not matter to "we." This would be associated with the perspective that volcanic risk is closely linked to local territory. However, given the potential for large eruptions that can cause devastating damages to a wider region, this perspective would be a barrier to appropriately understanding the severity of more catastrophic volcanic risks.

Finally, a few comments concerning the News A article had readers evaluating a risk management plan. Although no comments refuted the effectiveness of shelters on ash deposit prevention, some raised questions about volcanic risk management, as follows:

- “...volcanic hazards not only include rocks flying out of the volcano but also pyroclastic flow. How can we protect ourselves against the risk of pyroclastic flow? Mt. Ontake and Mt. Fuji are active volcanoes. An active volcano will erupt someday. Even knowledgeable volcanologists cannot predict when an eruption will occur." 


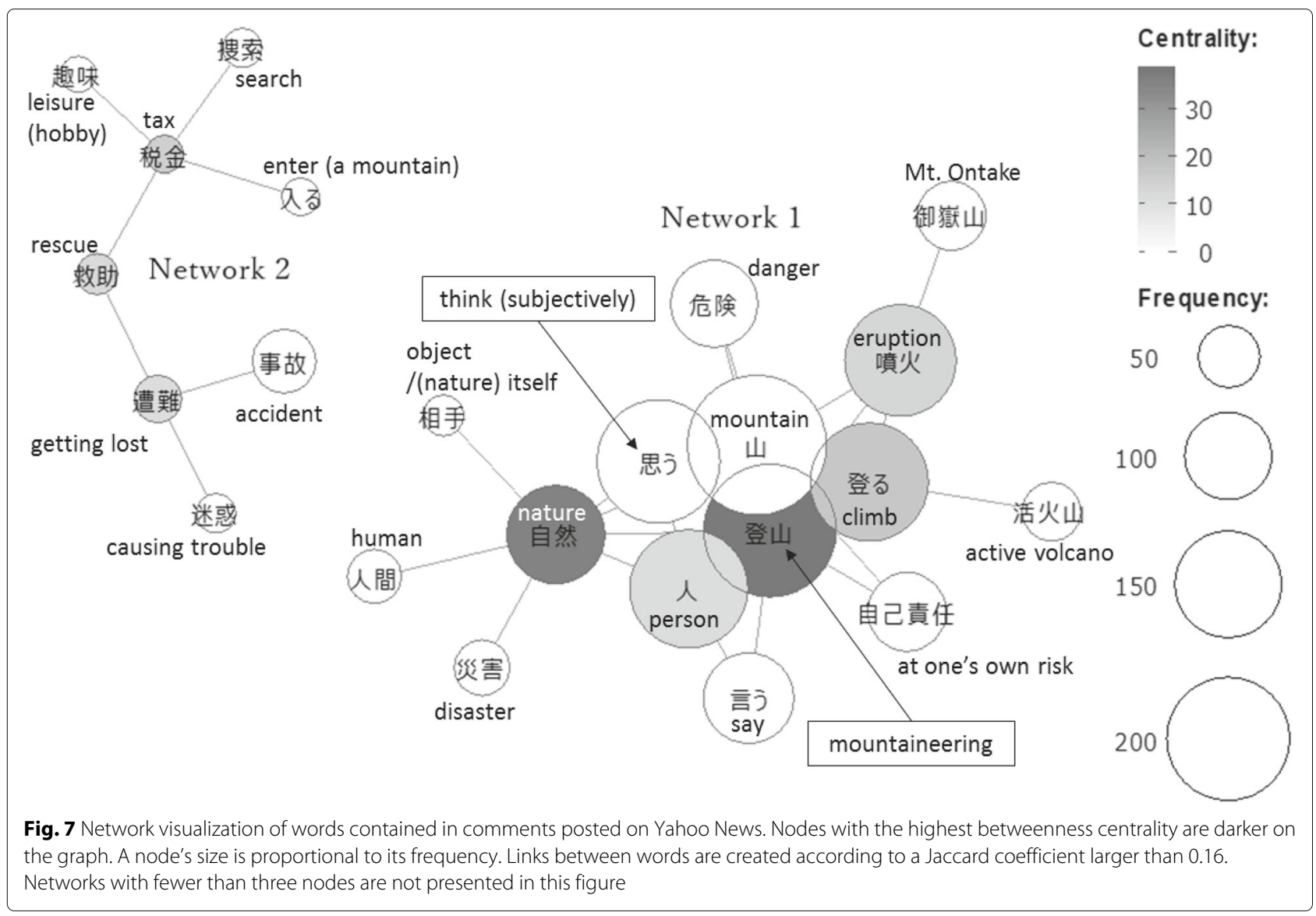

- "It is impossible to assume that a volcano is safe...a shelter cannot withstand a pyroclastic flow."

Readers pointed out that a shelter is powerless against pyroclastic flow. Furthermore, one reader used the case of the past volcanic disaster of Mt. Unzen in 1991, which killed 43 people, to underscore the force of a pyroclastic flow: "...A sudden pyroclastic flow killed many people at Unzen-Dake. Unexpected things will happen." Having learned about various kinds of volcanic phenomena from previous volcanic hazards, readers expressed the concept of the powerless human in their responses.

\section{Discussion: public responses with "we" and "others" in the context of volcanic risk}

As noted in existing literature surrounding the communication of volcanic risk through the media during a volcanic crisis (Valaskivi et al. 2019; Calabró et al. 2020), we observed discrepancies in the media's attention on volcanic risk. Not only does this lead to an information gap among the public, but it could also create a different collective memory. The national newspapers mainly concentrated on political information about volcanoes and human interest stories. Those obtaining information from the national newspapers could not find updated information on volcanic risk prevention following the 2014 Mt. Ontake eruption. This would prevent tourists from obtaining appropriate information, and also reduce the ability of the disaster prevention measures taken by cities around Mt. Ontake to recover from damage to reputations (Asahi Shimbun 2020). Furthermore, as seen from the time series of Clusters 2 and 3 , the reporting pattern of the national newspapers was sporadic. As the contexts of each volcanic risk prevention measure were systematically unconnected, this situation seems to reduce the power to create any broad forums that would allow for a discussion of volcanic risk. Kuri (2019) found that interest in volcanoes is an important factor that enhances awareness of volcanic risk. The national newspapers framed volcanic risk as a political issue. As pointed out by a previous study (Robinson 2009), this framing would put people's eyes on the competence of the administration to cope with volcanic risk, rather than on volcanic risk itself.

On the other hand, the local newspaper provided considerable coverage of the post-disaster reconstruction, reporting a variety of community activities as the recovery proceeded. There are 327 serialized articles with the title "Live with Volcanoes," which correspond to $22 \%$ of the 
Table 7 Examples of comments presented in networks 1 and 2

\begin{tabular}{|c|c|}
\hline Network \# & Examples of selected discourse \\
\hline \multirow[t]{5}{*}{1} & $\begin{array}{l}\text { - A mountain itself is dangerous, not to mention an } \\
\text { active volcano! Genuine mountain lovers prepare } \\
\text { substantially in advance of a climb, and will never } \\
\text { pass the buck to others [for ending up in a } \\
\text { dangerous situation]. }\end{array}$ \\
\hline & $\begin{array}{l}\text { — If you want to climb a volcano in a highly volcanic } \\
\text { country, please climb at your own risk. }\end{array}$ \\
\hline & $\begin{array}{l}\text { - No wonder mountaineering is dangerous. Not all } \\
\text { mountains can be climbed with ease, like tourist } \\
\text { spots. It is common sense that people climb at their } \\
\text { own risk. Furthermore, we need to recognize that it is } \\
\text { dangerous. Mt. Ontake is a holy mountain. } \\
\text { Mountaineering, as a leisure activity, should be } \\
\text { prohibited on this holy mountain in the first place. }\end{array}$ \\
\hline & $\begin{array}{l}\text { - People who are obsessed with climbing do not } \\
\text { take the risks involved seriously. You are going to an } \\
\text { active volcano. }\end{array}$ \\
\hline & $\begin{array}{l}\text { - Human beings are powerless before nature. } \\
\text { During a fun time, mountaineering on a clear } \\
\text { autumn day, mountain climbers suddenly lost their } \\
\text { lives. It's so sad; I can't bear it when I think about } \\
\text { [how the grieving families must feel]. }\end{array}$ \\
\hline \multirow[t]{4}{*}{2} & $\begin{array}{l}\text { - If a volcanic eruption occurs again, the cost of } \\
\text { rescuing victims comes out of taxes. I hope that the } \\
\text { local government retains the climbing regulations [in } \\
\text { this area]. }\end{array}$ \\
\hline & $\begin{array}{l}\text { — Please take part in mountaineering at your own } \\
\text { risk. If climbers call for aid, I hope they themselves will } \\
\text { pay to be rescued. }\end{array}$ \\
\hline & $\begin{array}{l}\text { - There is always a risk both on mountains and at } \\
\text { sea. No wonder that the disaster administrative } \\
\text { agency prohibited going to Mt. Ontake because an } \\
\text { unexpected eruption occurred. I wonder if it is } \\
\text { rational to allocate public funds to build multiple } \\
\text { shelters for recreational mountaineering? }\end{array}$ \\
\hline & $\begin{array}{l}\text { - In an ideal world, the police and self-defense } \\
\text { forces are inactive, but things don't go well like in a } \\
\text { TV] drama. I often read claims that victims should not } \\
\text { trouble them, but from another point of view, I feel } \\
\text { this claim is incorrect, since one of their jobs is to save } \\
\text { lives. We should be grateful for their activities and } \\
\text { hard work. It is impolite to think that "we are causing } \\
\text { [the police and self-defense forces] a lot of trouble." }\end{array}$ \\
\hline
\end{tabular}

total. The title "Live with Volcanoes" is also a metaphor for abandoning the zero-risk view of volcanoes. As shown in Table 3, the local newspaper holistically covered various topics regarding volcanic eruption risk in a well-balanced manner. Political, social, and technological issues should be offered when talking about community resilience, so that they could allow an informed debate on an acceptable level of risk for the community (Reghezza-Zitt et al. 2012). Hence, it was concluded that local newspaper could have some contributions to building resilience, as well as play an effective role in educating the affected population. When tourists come without caring volcanic disaster preparedness, this information gap may cause local people (including experts) to be confused about tourists' lack of knowledge (Asahi Shimbun 2020).

The news story is basically directed toward either the episodic frame or thematic frame. Episodically framed news stories utilize a particular individual's experience or a specific event, to illustrate social problems, while thematic frames place public issues into broader or abstract contexts and highlight how to improve social conditions that cause particular obstacles (Iyengar 1994). Previous works (Iyengar 1994; Gross 2008) presented that people who receive episodic stories are more likely to assign responsibility for the social issue to individuals rather than society, because episodic frames provide a sense of closer connection to individuals, and are relatively digestible compared to statistical information and generalizations. The media tend to prefer human interest stories because they are considered the content that people can easily empathize with Okuda (2009). In this study, we observed that some articles (i.e., Cluster 3 articles) covered human interest stories. Nakagoshi and Inamasu (2019) conducted a web survey on framing effects, and revealed that people's perceptions of problems depend on how they are portrayed. They found that the effect of episodic frames on receivers was consistent with previous studies. Fifth anniversary coverage on Yahoo News was also framed episodically, rather than thematically. Further, many episodically framed stories circulated in the anniversary month. As mentioned above, it was found that readers argued that mountaineers were personally responsible for their troubles. Readers may endeavor to dispel anxiety by stigmatizing a certain group (in this case, mountaineers), and thinking that "getting rid of these people will bring a social solution" (Flynn et al. 2001). In other words, within the online sphere, a boundary of common in-group identity ("we") was created, and certain prejudice and discrimination was directed toward the out-group ("others").

The sense of fatalism that human beings are helpless in the face of a volcanic disaster was observed in our comment data. As we scrutinized a small number of Yahoo News articles, and it was difficult to obtain reliable demographic data about online readers due to the anonymity of the Internet, it was unclear whether the anniversary coverage would be more likely to elicit negative emotions (such as anger and disgust), rather than compassion and pity, in all cases. However, our finding that online comments had a negative tone is consistent with the outcomes of previous research (Yamada 2020). Furthermore, newspapers, especially national ones, emphasized that local governments were slow to make progress on volcano disaster prevention measures (see Table 5). This would decrease public confidence in the municipal ability to prevent volcanic disasters. Ohtomo and Iwasaki (2011) used an experimental study to gauge the strength 
of the relationship between exposure to mass media and preparedness behavior for earthquakes. There is a belief that one's efforts can control the extent of the damage inflicted by a natural catastrophe, and expectations surrounding the impact of preparedness behavior on disaster reduction could promote protective actions. However, the sense of fatalism and the perception of "we" and "others" could hamper concrete steps toward volcanic disaster prevention. We concluded that human interest reporting may not have been an alternative to vicarious experiences (Bandura 1977) in this case.

Some disaster studies have suggested that the usage of the term "natural disaster" offers people a misleading image (Massazza et al. 2019; Chmutina and von Meding 2019). The expression "natural disaster" could be a getout-of-jail-free card to take zero responsibility for failures of disaster preparedness measures by blaming nature. It affirms the status quo, and deprives our society of opportunities to change. It is thought that "hazards can turn into a disaster due to human acts of omission and commission rather than an act of nature," and that disasters are frequently brought about by socioeconomic factors rather than natural phenomena (Chmutina and von Meding 2019). In this case, the newspaper media frequently utilized the combination of the terms "disaster" and "eruption" instead of the expression "natural disaster" (see the network visualization diagram of words). Only 56 of the total (2797) articles contained the expression "natural disaster" in their text. However, it appears to have the same contribution in terms of producing the image that both expressions are of phenomena distinct from humanmade disasters. The important point is that journalists, as watchdogs, monitor whether policy and decision makers attempt to create an advantageous situation for themselves by portraying disasters as unforeseen and unexpected natural forces. It is crucial for journalists to ask elites or politicians hard-hitting questions that the public cannot. Occasional in-depth reporting is insufficient (Marder 1998). The media attention regarding the trial topic of the $2014 \mathrm{Mt}$. Ontake eruption is dependent on the trial schedule. The bereaved raised a question about the policy-making process with scientific advice. According to the OECD Science (), transparency in the political use of scientific advice is of utmost importance. Therefore, journalists need to endeavor to generate a debate on the sound application of scientific advice through their coverage.

As seen in Fig. 7, the expression "natural disaster" was used more in comments because of the direct link between "disaster" and "nature." This revealed that a sense of fatalism is widespread within Japanese society. When a disaster is conceived as a natural phenomenon, the perceived role of human actors is concealed. This is the case in all disasters, including this one. Opinions about excluding some people and the perceptions of natural responsibility may hinder the formation of a shared risk awareness of volcanic risk. These factors could have shaped a different collective memory of the 2014 Mt. Ontake eruption, such that it would not be viewed as an opportunity for social progress, but rather as a wound causing distress to society (namely through stigma).

\section{Conclusions}

We conducted a quantitative analysis of mass media coverage after the JMA lowered the alert level from 3 to 2 in 2015, investigating which topics were covered by news stories, and to what extent in order to answer the first research question. When the automatic text categorization splits the news articles into five topics, we found that stories about Mt. Ontake's volcanic warning status (Cluster 1 ) and human interest (Cluster 3 ) topics were primarily published during the anniversary months. While stories related to municipalities' volcanic emergency plans (Cluster 2) and lessons learned from the $2014 \mathrm{Mt}$. Ontake eruption (Cluster 4) were covered during ordinary months, stories on missing person searches (Cluster 5) were only reported in July and August 2015. The information volumes of Clusters 1,2, and 3, which we defined as the number of characters in articles, comprised approximately $25 \%$ of the total.

Similar to previous studies, the distributions of clusters for each newspaper form were distinct (see Table 3). For national newspapers, we ranked Clusters 2, 3, 1, 4, and 5 in order from the category with the largest information volume. National newspapers paid substantial attention to Cluster 2. As their readers primarily live in big cities like Tokyo and Osaka, the current status of countermeasures against volcanic disasters (which each municipality should establish) has become an important political issue for journalists working in the national press. The inherent news value resulted in enormous media attention in Cluster 2. Furthermore, human interest stories were covered by national media, constituting the second largest information volume. This would also be associated with the fact that many tourists were victims of the volcanic eruption.

For the regional newspaper that we examined (the Chunichi Shimbun), we arranged Clusters 1, 3, 4, 2, and 5 in descending order. In contrast to the national newspapers' lineup of clusters, the regional newspaper devoted less coverage to Cluster 2. In the inventory of this cluster, the information volumes of Clusters 1 and 3 comprised approximately $67 \%$ of the total. The stories belonging to these two categories primarily appeared during the anniversary months; we considered them to be topics with higher public attention because readers live around Mt. Ontake, as well as in the Aichi area. The number of articles assigned to Cluster 2 was small. The regional media covers the Chubu region, including Aichi, 
and gathers news related to disaster preparedness of the municipalities within the limited area. Since it cannot cover each region with the same resources as a local newspaper, it would be difficult to collect detailed newsworthy topics. This could be confirmed by the relatively high percentage of articles related to the trial held in Matsumoto city (the capital of Nagano Prefecture).

For the local newspaper (Shinano-Mainichi Shimbun), we arranged Clusters 1, 2, 3, 4, and 5 in descending order. The local newspaper had a somewhat higher information volume for Cluster 1 (approximately 30\%) than the other categories. On the other hand, the information volumes of Clusters 2, 3, and 4 were nearly the same at $20 \%$. We found that the local newspaper covered various topics in terms of volcanic eruption risk in a well-balanced manner. Since the main business for the region around Mt. Ontake is tourism, abandoning the zero-risk logic is a major disadvantage. However, according to Centemeri's study on the long term recovery process from the Seveso disaster (Italy's industrial disaster in 1976) (Centemeri 2015), "the possibility of transforming a stigmatizing accident that had been inflicted upon the community into an 'opportunity for change' entailed accepting the idea that some of its consequences would not serve in the construction of a collective cause." The local media played a role in coordinating the various opinions of the community and contributed to building resilient communities.

We conducted a content analysis of the online comments (to the articles referring to the fifth anniversary of the Mt. Ontake volcanic disaster) to establish how readers felt in response to the news coverage. This is the second part of our research questions. Only three articles were published on Yahoo News. According to the arguments made by the three articles, one article mainly belonged to Cluster 1, while the others belonged to Cluster 3 . The comments claimed that mountaineering should be performed at one's own risk and that administrative agencies need not take countermeasures against volcanic disasters. The readers indicated that any volcanic disaster prevention plan did not match the situation of a pyroclastic flow, and that building shelters might not be worth the cost. At the underlying level, commenters regarded volcanic eruptions as something beyond human wisdom, suggesting a fatalism of throwing their hands up for the prevention of volcanic disasters. Overall it can be said that the commenters felt volcanic risk to be an issue pertaining to mountaineers, or "others," instead of being relevant to themselves, or "we."

\section{Limitations and outlook}

Our study had certain limitations. In this study, we focused on news articles regarding the $2014 \mathrm{Mt}$. Ontake eruption reported by the newspapers. Here, we lumped the five newspaper companies together as the national newspaper. But each has its own political ideology and therefore the phenomenon of polarization in newspapers' stances toward the government is observed. If we will look at polarization in opinions towards the government's commitment to disaster risk reduction, news articles covered by respective newspaper companies should be investigated separately.

Furthermore, as mentioned above, newspaper subscription rates vary within generations (Institute for Information and Communications Policy 2019). Fundamentally, young people tend to use electronic media such as web news portals and social media, rather than print media, in acquiring news. In addition, people consider televised media as the most reliable source for obtaining information about the world. Newspapers are highly trusted as media, but are not widely read (Institute for Information and Communications Policy 2019). Even though journalists share common news selection criteria, each media applies different types of framing to news. Previous research has suggested that the human interest frame, which is similar to the episodic frame, may be more prevalent in media coverage of crises (Semetko and Valkenburg 2000; An and Gower 2009). According to the frame analysis of health issues (Cho 2006), episodically framed news stories dominate televised media. Our results of the content analysis of online comments show that readers imposed the responsibilities of volcanic disasters on climbers. While this study looked at three online news stories and readers' online reactions to them, there is insufficient data to derive generalizations. Moreover, TV news was not examined. Although it is difficult to gauge the audience's reaction to TV news, comments on social media with quotations or references to TV news allow us to comprehend the effect of TV news frames to some extent. It will be necessary in the future to conduct a content analysis of comments containing the quotations of news organizations on social media.

Our sample size for the content analysis of online comments was too limited to verify whether it is possible to observe a negative feeling toward certain people (e.g., mountaineers) and administrative agencies that try to take countermeasures against volcanic disasters. Future research could involve a content analysis of multiple comments referring to the $2014 \mathrm{Mt}$. Ontake eruption and other volcanic calamities on online platforms (such as Twitter). Previous studies suggest that media exposure positively influences people's emergency preparedness behavior and risk perception (Hong et al. 2019). Hence, the dominant frame in media anniversary coverage is one of the determining factors affecting emergency preparedness behavior. In our study, we were unable to determine who wrote the comments due to the ubiquitous, often anonymous nature of the Internet. Therefore, we were unable to identify the characteristics of readers 
with negative views. Using interviews or questionnaire surveys (Donovan et al. 2018; Kuri and Suppasri 2018), future investigations could extend the current research by ironing out how the different frames of news coverage moderate the relationship between socio-demographic features and public discourse on proper measures to adopt for volcanic disaster prevention.

Despite these limitations, our findings provide direction for future volcano risk communication strategies. In the digital age, civic entities (such as non-profit and non-governmental organizations) that make full use of information technology are important for building a communication strategy for volcanic risk. In the online world, certain groups are secluded due to the filter bubble effect (Pariser 2011). Based on Tocqueville's institutional theory (de Tocqueville 1969), these groups lose social ties to others on the Web. Furthermore, people have no opportunity to acquire ideas from others in terms of handling various volcanic risks in everyday life because the issue of volcanic risk is usually inconspicuous. Thus, the direction of discourse on the Web is vulnerable to the propagation of misinformation (Aswani et al. 2019). A civic body that bridges the gap between isolated groups and government bodies or experts (Putnam 2001) can play a pivotal role in building Web communication strategies, and provide different sides of the opinion spectrum for isolated groups. This kind of civic group would also be meaningful because it enables the spread of copious information beyond administrative districts, in addition to serving as a watchdog for the central/local governments. During volcanic crises, it is very important to deliver one-voice messages from experts to society (Harris 2015a; Harris and Villeneuve 2018b). Such civic groups may be beneficial for monitoring the potential propagation of misinformation or rumors at that time. In the future, it will be necessary to add civic groups as another actor to the tetrahedron proposed by Okada and Ui (1997).

The rise of SNS has weakened the power of newspapers to convey information; in the future, only fragmented information on volcanic risk will be shared. Therefore, it is natural to assume that the information gap will grow increasingly larger. People also seem to presume that volcanic disasters occur in areas with volcanoes. Volcanic disaster prevention at Mt. Fuji has significant news value (Yamada 2017), whereas such efforts made at other sites are unlikely to be widely reported. Thus, people underestimate the potential hazards of volcanic eruptions. How to modify such an inaccurate perception in the age of information and communications technology is a question beyond the scope of this study. However, the key approach to addressing the matter of volcanic risk would involve filling the information gap and not stigmatizing anyone. The design of volcanic risk management will require the active commitment of government agencies and experts, and a sophisticated communication strategy for volcanic information should be developed. For that, it would be necessary to establish a specialized institution that develops disaster management strategies centrally, for the entire nation.

\section{Supplementary Information}

The online version contains supplementary material available at https://doi.org/10.1186/s13617-021-00113-8.

Additional file 1: Relationships between $N_{c} / N$ and $N_{c a} / N_{c}$. Scatterplot showing the relationship between $N_{c} / N$ (the $x$-axis) and $N_{c a} / N_{c}$ (the $y$-axis) for (a) national, (b) regional, (c) local, and (d) all newspapers. The number corresponds to the cluster number. Here, $N, N_{c}$, and $N_{c a}$ signal the overall information volume, the total information volume for each cluster, and the information volume during the anniversary months for each cluster, respectively. See Table 3 for a detailed description.

Additional file 2: Network visualization of words and monthly variations in information volume for cluster 5. The same as Fig. 3, but for Cluster 5. In panel (a), links between words are created according to a cosine similarity larger than 0.62 .

Additional file 3: Network visualization of words centered on the word "expert". The same as Fig. 3, but we plotted words co-occurring with the word "expert" and used a list of words appearing in the articles that referred to the lawsuit brought against the local government and the JMA by the bereaved. Links between words are created according to a cosine similarity greater than 0.66 .

\section{Acknowledgements}

The authors thank two anonymous reviewers for their valuable suggestions and comments to this paper. We also thank the members of the Plurilingualism and Social Interactions Research Group (Waseda University) for their invaluable comments. We would like to thank Editage (www.editage.com) for English language editing. This work was supported by Waseda University Grant for Special Research Projects, Grant Number 2019C-018.

\section{Author's contributions}

The project was conceived of by the author. Data collection, figure production, and manuscript preparation and editing were done by the author. The author read and approved the final manuscript.

\section{Declarations}

\section{Competing interests}

The author declares that he have no competing interests.

Received: 6 June 2020 Accepted: 18 November 2021

Published online: 07 January 2022

\section{References}

Aaldering L, Vliegenthart R (2016) Political leaders and the media. can we measure political leadership images in newspapers using computer-assisted content analysis? Qual Quant 50:1871-1905. https:// doi.org/10.1007/s11135-015-0242-9

Adam B (2004) Memory of futures. KronoScope 4(2):297-315. https://doi.org/ $10.1163 / 1568524042801392$

Aggarwal CC (2018) Machine Learning for Text. Springer, Tokyo. https://doi. org/10.1007/978-3-319-73531-3

Aggarwal CC, Reddy CK (2013) DATA CLUSTERING Algorithms and Applications. CRC Press, New York

Aichi Prefecture (2018) Financial Status of Aichi Prefecture. http://www. chihousai.or.jp/english/07/pdf/2018_Aichi.pdf. Accessed 31 May 2020 An S-K, Gower KK (2009) How do the news media frame crises? a content analysis of crisis news coverage. Public Relat Rev 35(2). https://doi.org/10. 1016/j.pubrev.2009.01.010 
Asahi Shimbun (2020) Six Years After the 2014 Eruption of Mt. Ontake, Five People Are Still Missing

Aswani R, Kar AK, llavarasan PV (2019) Experience: managing misinformation in social media - insights for policy makers from the twitter analytics. J Data Inf Qual 12(1). https://doi.org/10.1145/3341107

Bandura A (1977) Self-efficacy: Toward a unifying theory of behavioral change. J Environ Psychol 84(2):191-215. https://doi.org/10.1037/0033-295X.84.2. 191

Borgatti SP (2005) Centrality and network flow. Soc Netw 27(1):55-71. https:// doi.org/10.1016/j.socnet.2004.11.008

Buckner RL, Sepulcre J, Talukdar T, Krienen FM, Liu H, Hedden T, Andrews-Hanna JR, Sperling RA, Johnson KA (2009) Cortical hubs revealed by intrinsic functional connectivity: mapping, assessment of stability, and relation to alzheimer's disease. J Neurosci Off J Soc Neurosci 29(6):1860-1873. https://doi.org/10.1523/JNEUROSCI.5062-08.2009

Büettcher S, Clarke CLA, Cormack GV (2010) Information Retrieval: Implementing and Evaluating Search Engines. MIT Press, London

Cabinet Office (2017) Public Opinion Survey on Disaster Prevention. https:// survey.gov-online.go.jp/h29/h29-bousai/index.html. Accessed 30 May 2020

Calabró L, Harris AJL, Thouret J (2020) Media views of the stromboli 2002-2003 eruption and evacuation: a content analysis to understand framing of risk communication during a volcanic crisis. J Appl Volcanol 9(5). https://doi. org/10.1186/s13617-020-00094-0

Centemeri L (2015) Investigating the "Discrete Memory" of the Seveso Disaster in Italy. In: Revet S, Langumier J (eds). Governing Disasters. Beyond Risk Culture. Palgrave Macmillan US. pp 191-219. https://doi.org/10.1057/ 9781137435460_7

Chmutina K, von Meding J (2019) A dilemma of language: "natural disasters" in academic literature. Int J Disaster Risk Sci 10. https://doi.org/10.1007/ s13753-019-00232-2

Cho S (2006) Network news coverage of breast cancer, 1974 to 2003. J Mass Commun Q 83(1). https://doi.org/10.1177/107769900608300108

Damstra A, Jacobs L, Boukes M, Vliegenthart R (2019) The impact of immigration news on anti-immigrant party support: unpacking agenda-setting and issue ownership effects over time. J Elections Public Opin Parties:1-22. https://doi.org/10.1080/17457289.2019.1607863

de Tocqueville A (1969) Democracy in America. Lawrence, George (trans.) and Payer, J P (ed.), Doubleday, New York

Donovan A, Suppasri A, Kuri M, Torayashiki T (2018) The complex consequences of volcanic warnings: Trust, risk perception and experiences of businesses near mount Zao following the 2015 unrest period. Int J Disaster Risk Reduction 27:57-67. https://doi.org/10.1016/j.ijdrr.2017.09.023

Drieger P (2013) Semantic network analysis as a method for visual text analytics. Proc Soc Behav Sci 79:4-17. https://doi.org/10.1016/j.sbspro.2013.05.053

Edgerton G (2000) Television as historian: An introduction. Film Hist Interdiscip J Film Telev Stud 30(1):7-12. https://www.muse.jhu.edu/article/400195

Edy JA (2019) Collective memory. Int Encycl Journal Stud. https://doi.org/10. 1002/9781118841570.iejs0016

Evans ST, Holme R, Pooley JA (2004) Cyclone Preparedness in Northwest Australia : Stage One Report 2004. Fire and Emergency Services Authority, Western Australia. https://trove.nla.gov.au/version/177773449

Federal Emergency Management Agency (2006) Principles of Emergency Management, Independent Study, IS230. https://training.fema.gov/is/ courseoverview.aspx?code=IS-230.d. Accessed 10 Dec 2020

Flynn J, Slovic P, Kunreuther H (2001) Risk, Media, and Stigma: Understanding Public Challenges to Modern Science and Technology. Earthscan, London

Forrest RT (1993) Disaster anniversay: A social reconstruction of time. Sociol Inq 63(4). https://doi.org/10.1111/j.1475-682X.1993.tb00323.x

Fujita A, Takahashi DY, Patriota AG (2014) A non-parametric method to estimate the number of clusters. Comput Stat Data Anal 73:27-39. https:// doi.org/10.1016/j.csda.2013.11.012

Gross K (2008) Framing persuasive appeals: Episodic and thematic framing, emotional response, and policy opinion. Political Psychol 29(2). https://doi. org/10.1111/j.1467-9221.2008.00622.x

Hagiwara S (2000) Duplication and differentiation of news reported by TV and newspapers media. J Mass Commun Stud 57. https://doi.org/10.24460/ mscom.57.0_95

Halbwachs M (1992) On Collective Memory. University of Chicago Press, Chicago

Harris AJL (2015) Forecast communication through the newspaper part 1: framing the forecaster. Bull Volcanol 77(29). https://doi.org/10.1007/ s00445-015-0899-x
Harris AJL (2015) Forecast communication through the newspaper part 2: perceptions of uncertainty. Bull Volcanol 77(30). https://doi.org/10.1007/ s00445-015-0902-6

Harris AJL, Gurioli L, Hughes EE, Lagreulet S (2012) Impact of the Eyjafjallajökull ash cloud: A newspaper perspective. J Geophys Res Solid Earth 117(3). https://doi.org/10.1029/2011JB008735

Harris AJL, Villeneuve N (2018) Newspaper reporting of the april 2007 eruption of Piton de la Fournaise part 1: useful information or tabloid sensationalism? J Appl Volcanol 7(4). https://doi.org/10.1186/s13617-0180073-1

Harris AJL, Villeneuve N (2018) Newspaper reporting of the april 2007 eruption of Piton de La Fournaise, part 2: Framing the hazard. J Appl Volcanol 7(3). https://doi.org/10.1186/s13617-018-0072-2

Higuchi K (2016) A two-step approach to quantitative content analysis: KH coder tutorial using Anne of Green Gables (part I). Ritsumeikan Soc Sci Rev 52(3):77-91. http://www.ritsumei.ac.jp/file.jsp?id=325881

Higuchi K (2017) A two-step approach to quantitative content analysis: KH coder tutorial using Anne of Green Gables (part II). Ritsumeikan Soc Sci Rev 53(1):137-147. http://www.ritsumei.ac.jp/file.jsp?id=346128

Hong Y, Kim J-S, Xiong L (2019) Media exposure and individuals' emergency preparedness behaviors for coping with natural and human-made disasters. J Environ Psychol 63:82-91. https://doi.org/10.1016/j.jenvp.2019. 04.005

Institute for Information and Communications Policy (2019) The Survey Report on Information and Communication Media Usage Time and Information Behavior. https://www.soumu.go.jp/main_content/000644166.pdf. Accessed 10 Dec 2020

Ishimine Y (2016) Current status and issues of volcanic disaster mitigation in japan for effective cooperation between scientists and emergency responders. Bull Volcanol Soc Jpn 61(1). https://doi.org/10.18940/kazan.61.1_183

lyengar S (1994) Is Anyone Responsible? : How Television Frames Political Issues. University Of Chicago Press, Chicago and London

Japan Meteorological Agency (2018) Information: Mt. Ontake. https://www. data.jma.go.jp/svd/vois/data/tokyo/312_Ontakesan/312_index.html. Accessed 31 May 2020

Japan Meteorological Agency (2020) Volcanic Activity of Mt. Ontake Since Prehistoric Times. https://www.data.jma.go.jp/svd/vois/data/tokyo/ 312_Ontakesan/312_history.html. Accessed 10 Dec 2020

Japan Visitor.com (2020) Japanese Press and Newspapers. https://www. japanvisitor.com/japanese-culture/cult-japan-newspapers. Accessed 30 May 2020

Jenkins J, Nielsen RK (2020) Proximity, public service, and popularity: A comparative study of how local journalists view quality news. Journal Stud 21(2):236-253. https://doi.org/10.1080/1461670X.2019.1636704

Kadoguchi Y (2015) Application Example for Problem Visualization and Problem Analysis Using a Network Data Model. https://www.juse.jp/sqip/ symposium/archive/2015/day1/files/happyou_A2-1.pdf. Accessed 21 Dec 2020

Kawahara M (2020) [Python] I Used TF-IDF to Get the Features of My Blog. https://dev.classmethod.jp/articles/python-tfidf-blog/. Accessed 10 Dec 2020

Kim YC, Kang J (2010) Communication, neighbourhood belonging and household hurricane preparedness. Disasters 34(2):470-488. https://doi. org/10.1111/j.1467-7717.2009.01138.x

Kitch C, Hume J (2007) Journalism in a Culture of Grief. Routledge, New York

Kiyohara S, Maeshima K, Owen D (2018) Internet Election Campaigns in the United States, Japan, South Korea, and Taiwan. Springer, Switzerland. https://doi.org/10.1007/978-3-319-63682-5

Kligler-Vilenchik N, Tsfati Y, Meyers O (2014) Setting the collective memory agenda: Examining mainstream media influence on individuals' perceptions of the past. Mem Stud 7(4):484-499. https://doi.org/10.1177/ 1750698014523443

Kroepsch A, Koebele E, Crow D, Berggren J, Huda J, Lawhon L (2018) Remembering the past, anticipating the future: Community learning and adaptation discourse in media commemorations of catastrophic wildfires in colorado. Environ Commun 12(1):132-147. https://doi.org/10.1080/ 17524032.2017.1371053

Kudo T, Yamamoto K, Matsumoto Y (2004) Applying conditional random fields to japanese morphological analysis. In: Proceedings of the 2004 Conference on Empirical Methods in Natural Language Processing. Association for Computational Linguistics. pp 230-237. https:// aclanthology.org/W04-3230/ 
Kuri M (2019) Recent perceptions of volcanic hazard-related information in japan: Expectation of eruption predictability and acceptance of uncertainty. J Disaster Res 14(8):1072-1085. https://doi.org/10.20965/jdr. 2019.p1072

Kuri M, Suppasri A (2018) Perceptions of volcanic hazard-related information relevant to volcano tourism areas in Japan. J Disaster Res 13(6):57-67. https://doi.org/10.20965/jdr.2018.p1082

Laed.com (2020) Spearman's Rank-Order Correlation. https://statistics.laerd. com/statistical-guides/spearmans-rank-order-correlation-statisticalguide.php. Accessed 21 Dec 2020

Lau JH, Baldwin T (2016) An empirical evaluation of doc2vec with practical insights into document embedding generation. In: Proceedings of the 1st Workshop on Representation Learning for NLP. Association for Computational Linguistics. pp 78-86. https://www.aclweb.org/anthology/ W16-1609/

Le Q, Mikolov T (2014) Distributed representations of sentences and documents. In: Xing EP, Jebara T (eds). Proceedings of the 31st International Conference on Machine Learning. PMLR Vol. 32. http:// proceedings.mlr.press/v32/le14.pdf

Le-Khac NA, Bue M, Whelan M, Kechadi MT (2010) A clustering-based data reduction for very large spatio-temporal datasets. In: Cao L, Feng Y, Zhong J (eds). Advanced Data Mining and Applications. ADMA 2010. Lecture Notes in Computer Science. Springer. pp 43-54. https://doi.org/10.1007/ 978-3-642-17313-4_5

Li H, Lee C (2013) Remembering Tiananmen and the Berlin Wall: the elite U.S, press's anniversary journalism, 1990-2009. Media Cult Soc 35(7):830-846. https://doi.org/10.1177/0163443713495077

Licata L, Mercy A (2015) Collective memory, social psychology of. In: Wright JD (ed). International Encyclopedia of the Social and Behavioral Sciences, 2nd ed. Elsevier, Oxford. pp 194-199

Liu C, Lu X (2018) Analyzing hidden populations online: topic, emotion, and social network of HIV-related users in the largest chinese online community. BMC Med Inf Decis Making 18(2). https://doi.org/10.1186/ s12911-017-0579-1

Marder M (1998) This is watchdog journalism. Nieman Rep 53-54((4:winter 1999) and (1:spring 2000)). https://niemanreports.org/articles/1998-this-iswatchdog-journalism/

Massazza A, Brewin CR, Joffe H (2019) The nature of "natural disasters" : Survivors' explanations of earthquake damage. Int J Disaster Risk Sci 10 https://doi.org/10.1007/s13753-019-0223-z

McCombs M, Shaw D (1972) The agenda-setting function of mass media. Public Opin Q 36(2):176-187. https://doi.org/10.1086/267990

Milligan GW, Cooper MC (1985) An examination of procedures for determining the number of clusters in a data set. Psychometrika 50:159-179. https:// doi.org/10.1007/BF02294245

Ministry of Education, Culture, Sports, Science and Technology (2015) Relationship between major sources of information on science and technology and consciousness. http://www.nistep.go.jp/wp/wp-content/ uploads/NISTEP-DP121-FullJ1.pdf. Accessed 30 May 2020

Mizude K (2016) Memories of disasters on Disaster Preparedness Day: Newspaper editorials on anniversaries of the Great Kanto Earthquake, 1924-2014. J Mass Commun Stud 88. https://doi.org/10.24460/mscom.88. $0 \quad 157$

Mukaka MM (2012) Statistics corner: A guide to appropriate use of correlation coefficient in medical research. J Med Assoc Malawi 24(3):69-71. https:// www.ncbi.nlm.nih.gov/pmc/articles/PMC3576830/

Nagano Prefecture (2017) Mt. Ontake Kazan Meister. https://www.ontakevolcano.jp/ontake-meister/. Accessed 31 May 2020

Nakagoshi M, Inamasu K (2019) Effects of media framing and informational positions on the attribution of responsibility for welfare: Who is "responsible" for it - the government or recipients? Jpn J Soc Psychol 35(2). https://doi.org/10.14966/jssp.1901

Nakai D (2018) The japanese media in flux: Watchdog or fake news?. In: Japan Future Initiative (ed). Mass Media in Japan, Fake News in the World, Reexamining Japan in Global Context Forum: 2 April 2018; Tokyo. Suntory Foundation. pp 2-5. https://www.suntory.com/sfnd/jgc/forum/013/pdf/ 013.pdf

National Institute for Environmental Studies (2015) Public opinion polls on Japanese lifestyle. https://www.nies.go.jp/whatsnew/2015/20151130/ 20151130.html. Accessed 30 May 2020

Neuman WR, Guggenheim L, Jang SM, Bae SY (2014) The dynamics of public attention: Agenda-setting theory meets big data. J Commun 64(2):193-214. https://doi.org/10.1111/jcom.12088
Nick C (2012) Media, Society, World: Social Theory and Digital Media Practice. Polity Press, Cambridge

Nowotny H (2008) Insatiable Curiosity: Innovation in a Fragile Future. MIT Press, Cambridge

OECD Science, Technology and Industry Policy Papers Scientific Advice for Policy Making: The Role and Responsibility of Expert Bodies and Individual Scientists. https://doi.org/10.1787/5js33/1jcpwb-en. Accessed 13 Dec 2020

Ohtomo S, Iwasaki S (2011) The effects of the media on the motivations of earthquake preparedness. J Soc Risk Anal 21(1):33-42. https://doi.org/10. $11447 /$ sraj.21.33

Okada H (2015) The gap between monitoring and prior evacuation: Asking the meaning of integrated power of disaster mitigation for volcanic eruptions. J Disaster Inf Stud 13

Okada H, Ui T (1997) Eruption prediction and disaster prevention and mitigation. In: Ui T (ed). Volcanic Eruption and Disaster. University of Tokyo Press, Tokyo. pp 79-116

Okuda Y (2009) Ethics in the broadcasting industry sphere in question. from the BPO investigation committee's case. NHK Mon Rep Broadcast Res 53. https://www.nhk.or.jp/bunken/research/domestic/20090130_5.html

Pantti M, Wahl-Jorgensen K, Cottle S (2012) Disasters and the Media. Peter Lang Pub Inc., New York

Pariser E (2011) The Filter Bubble: What the Internet Is Hiding from You. Penguin Press, New York

Patil C, Baidari I (2019) Estimating the optimal number of clusters k in a dataset using data depth. Data Sci Eng Vol 4:132-140. https://doi.org/10.1007/ s41019-019-0091-y

Paton D (2003) Disaster preparedness: a social-cognitive perspective. Disaster Prev Manag 12(3):210-216. https://doi.org/10.1108/09653560310480686

Paton D, Bajek R, Okada N, Mclvor D (2010) Predicting community earthquake preparedness: across-cultural comparison of japan and new zealand, natural hazards. Nat Hazards J Int Soc Prev Mitig Nat Hazards 54(3):765-781. https://doi.org/10.1007/s11069-010-9500-2

Pérez-Lugo M (2004) Media uses in disaster situations: A new focus on the impact phase. Sociol Inq 74(2). https://doi.org/10.1111/j.1475-682X.2004. 00087.x

Perry RW, Lindell MK (1990) Predicting long term adjustment to volcano hazard. Int J Mass Emergencies Disasters 8(2):117-136. http://ijmed.org/ articles/27/download/

Peterson DW (1988) Volcanic hazards and public response. J Geophys Res Solid Earth 93. https://doi.org/10.1029/JB093iB05p04161

Pollock CJ (2014) Media and Social Inequality: Innovations in Community Structure Research. Routledge, New York

Putnam RD (2001) Bowling Alone: The Collapse and Revival of American Community. Simon and Schuster, New York

Quarantelli EL (1996) The future is not the past repeated: Projecting disasters in the 21st century from current trends. J Conting Crisis Manag 4(4). https:// doi.org/10.1111/j.1468-5973.1996.tb00097x

Reghezza-Zitt M, Rufat S, Djament-Tran G, Blanc LA, Lhomme S (2012) What resilience is not: Uses and abuses. Cybergeo. https://journals.openedition. org/cybergeo/25554

Reuters Institute (2019) Reuters Institute Digital News Report 2019. http:// www. digitalnewsreport.org/. Accessed 31 May 2020

Robinson S (2009) 'We were all there': Remembering America in the anniversary coverage of Hurricane Katrina. Mem Stud 2(2):235-253. https://doi.org/10.1177/1750698008102054

Rodríguez H (1997) A socioeconomic analysis of hurricanes in puerto rico: An overview of disaster mitigation and preparedness. In: Diaz HF, Pulwarty RS (eds). Hurricanes. Springer, Berlin. pp 121-143

Rousseeuw PJ (1987) Silhouettes: A graphical aid to the interpretation and validation of cluster analysis. J Comput Appl Math 20:53-65. https://doi. org/10.1016/0377-0427(87)90125-7

Schwartz B (1990) The reconstruction of Abraham Lincoln. In: Middleton D, Edwards D (eds). Collective Remembering. SAGE Publications, London. pp 81-107

Semetko H, Valkenburg P (2000) Framing european politics: A content analysis of press and television news. J Commun 50(2). https://doi.org/10.1111/j. 1460-2466.2000.tb02843.x

Showalter PS (1993) Prognostication of doom: An earthquake prediction's effect on four small communities. Int J Mass Emergencies Disasters 11(3):279-292. http://ijmed.org/articles/435/download/

Su C (2012) One earthquake, two tales:narrative analysis of the tenth anniversary coverage of the 921 earthquake in Taiwan. Media Cult Soc 34(3):280-295. https://doi.org/10.1177/0163443711433664 
Tajima Y (2017) Role of volcanic hazard maps and scenarios for the mitigation of volcanic disasters in Japan. Bull Volcanol Soc Jpn 62(2). https://doi.org/ 10.18940/kazan.62.2_61

Takeshita T (2008) The Agenda-Setting Function of the Media (Expanded Edition). Gakubunsha, Tokyo

Tekeli-Yesil S, Kaya M, Tanner M (2019) The role of the print media in earthquake risk communication: information available between 1996 and 2014 in Turkish newspapers. Int J Disaster Risk Reduction 33:284-289. https://doi.org/10.1016/j.ijdrr.2018.10.014

The volcanic emergency mitigation plan committee for Sabo of the Ontake volcano (2018) Mt. Ontake; volcano eruption emergency mitigation measures. https://www.cbr.mlit.go.jp/tajimi/sabo/ontake/gensai/ ontakesan-gensaikeikaku.pdf. Accessed 30 May 2020

Tierney KJ, Lindell MK, Perry RW (2001) Facing the Unexpected: Disaster Preparedness and Response in the United States. Joseph Henry Press, Washington DC

Trümper S, Broer IG (2019) Non-commemorative memory in news production: Discovering underlying motivations for journalists' memory work. Mem Stud. https://doi.org/10.1177/1750698019863158

Tsunematsu K, Ishimine Y, Kaneko T, Yoshimoto M, Fuji T, Yamaoka K (2016) Estimation of ballistic block landing energy during 2014 Mount Ontake eruption. Earth Planet Space 68(88). https://doi.org/10.1186/s40623-0160463-8

Unagami T, Kouda S, Watanabe M, Inoue Y, Tanabe S, Okamura S (2012) Cultural/environmental psychological discussion on risk perception. Saf Eng 51(3). https://doi.org/10.18943/safety.51.3_165

United Nations (2015) Sendai framework for disaster risk reduction 2015-2030. https://www.preventionweb.net/files/43291_sendaiframeworkfordrren. pdf. Accessed 30 May 2020

Valaskivi K, Rantasila A, Tanaka M, Kunelius R (2019) Towards a Geography of Mediated Affect: Discursive Spaces and Emotional Dynamics. In: Traces of Fukushima. Palgrave Pivot, Singapore. https://doi.org/10.1007/978-98113-6864-6_4

van Dijck J (2007) Mediated Memories in the Digital Age. Stanford University Press, Stanford

Vidal MC, Fujita A (2017) Package 'anocva'. https://cran.r-project.org/web/ packages/anocva/anocva.pdf. Accessed 31 May 2020

Wendelin M, Engelmann I, Neubarth J (2017) User rankings and journalistic news selection. Journal Stud 18(2). https://doi.org/10.1080/1461670X. 2015.1040892

Wenger D, Friedman B (1986) Local and national media coverage of disasters: A content analysis of the printed media's treatment of disaster myths. Int J Mass Emergencies Disasters 4(3). https://udspace.udel.edu/handle/19716/ 2762

Yamada K (2017) Text mining analysis of volcanological information in newspaper coverage. Bull Volcanol Soc Jpn 62(4):147-175. https://doi.org/ 10.18940/kazan.62.4_147

Yamada K (2019) A quantitative content analysis of the coverage of seismological news in japanese newspapers, 1990 to 2016. Zisin 71:161-183. https://doi.org/10.4294/zisin.2018-2

Yamada K (2020) Public response to news reports on the mount Kusatsu-Shirane volcanic eruption: A content analysis of online reader comments. Int J Disaster Risk Reduction 43:101388. https://doi.org/10. 1016/j.ijdr.2019.101388

Yeo J, Knox C (2019) Public attention to a local disaster versus competing focusing events: Google trends analysis following the 2016 Louisiana flood. Interdiscip Soc Sci Coast Resilience 100(7):2542-2554. https://doi. org/10.1111/ssqu.12666

Yomiuri Shimbun (2019) The Yomiuri Shimbun Media Data 2020. https://adv. yomiuri.co.jp/mediadata/files/mediadata2020.pdf. Accessed 30 May 2020

Řehưřek R, Sojka P (2010) Software framework for topic modeling with large corpora. In: Calzolari N (ed). Proceedings of the LREC 2010 Workshop on New Challenges for NLP Frameworks. University of Malta. pp 45-50. http:// www.fi.muni.cz/usr/sojka/presentations/lrec2010-poster-rehurek-sojka. pdf

\section{Publisher's Note}

Springer Nature remains neutral with regard to jurisdictional claims in published maps and institutional affiliations.

Ready to submit your research? Choose BMC and benefit from:

- fast, convenient online submission

- thorough peer review by experienced researchers in your field

- rapid publication on acceptance

- support for research data, including large and complex data types

- gold Open Access which fosters wider collaboration and increased citations

- maximum visibility for your research: over $100 \mathrm{M}$ website views per year

At BMC, research is always in progress.

Learn more biomedcentral.com/submissions 